\title{
Why Has the Cyclicality of Productivity Changed? What Does It Mean?
}

\author{
John G. Fernald \\ Federal Reserve Bank of San Francisco \\ J. Christina Wang \\ Federal Reserve Bank of Boston
}

April 2016

Working Paper 2016-07

http://www.frbsf.org/economic-research/publications/working-papers/wp2016-07.pdf

\section{Suggested citation:}

Fernald, John G., J. Christina Wang. 2016. "Why Has the Cyclicality of Productivity Changed? What Does It Mean?” Federal Reserve Bank of San Francisco Working Paper 2016-07. http://www.frbsf.org/economic-research/publications/working-papers/wp2016-07.pdf

The views in this paper are solely the responsibility of the authors and should not be interpreted as reflecting the views of the Federal Reserve Bank of San Francisco or Boston, or the Board of Governors of the Federal Reserve System. 


\title{
Why Has the Cyclicality of Productivity Changed? What Does It Mean?
}

\begin{abstract}
U.S. labor and total factor productivity have historically been procyclical-rising in booms and falling in recessions. After the mid-1980s, however, TFP became much less procyclical with respect to hours while labor productivity turned strongly countercyclical. We find that the key empirical "fact" driving these changes is reduced variation in factor utilization - conceptually, the workweek of capital and labor effort. We discuss a range of theories that seek to explain the changes in productivity's cyclicality. Increased flexibility, changes in the structure of the economy, and shifts in relative variances of technology and "demand" shocks appear to play key roles.
\end{abstract}

John G. Fernald and J. Christina Wang

Keywords: Procyclical productivity, labor hoarding, business cycles, growthaccounting, DSGE models JEL Codes: E23, E22, E32, O47

John Fernald is a senior research advisor in the economic research department of the Federal Reserve Bank of San Francisco. His email address is john.fernald@sf.frb.org J. Christina Wang is a senior economist and policy advisor in the research department of the Federal Reserve Bank of Boston. Her email address is christina.wang@researchfed.org.

We thank Susanto Basu for helpful conversations and comments. We thank Daniel Molitor for excellent research assistance.

This paper, which may be revised, is available on the web site of the Federal Reserve Bank of Boston at http://www.bostonfed.org/economic/ppdp/index.htm.

The views expressed in this paper are those of the authors and do not necessarily reflect those of the Federal Reserve Banks of San Francisco or Boston, or others associated with those institutions.

This version: December 2015 


\section{Introduction}

Historically, U.S. labor productivity (output per hour) and total factor productivity (TFP) rose in booms and fell in recessions. Different models of business cycles explain this procyclicality differently. Traditional Keynesian models relied on "factor hoarding," that is variations in how intensively labor and capital were utilized over the business cycle. Real business cycle (RBC) models instead posit that procyclical technology shocks drive the business cycle. Bernanke and Parkinson (1991) and Basu and Fernald (2001) emphasize that understanding cyclical productivity provides insight into the relative merits of alternative models.

Since the mid-1980s, however, the procyclicality of productivity has waned. TFP has been roughly acyclical with respect to inputs, whereas labor productivity has become significantly countercyclical. ${ }^{1}$ The slow pace of productivity growth after 2010 , when the postGreat Recession recovery gained a firm footing, is broadly consistent with these patterns.

In this paper, we seek to understand empirically the forces behind the changing cyclicality of productivity. Methodologically, we rely on growth accounting to derive and decompose productivity measures. We focus primarily on correlation with inputs and output to measure cyclicality, though we also incorporate VAR evidence on dynamic correlations.

First, we review the evidence on changes in productivity's cyclicality using the quarterly business-sector TFP dataset in Fernald (2014a). ${ }^{2}$ We discuss robustness to different measures of output and different surveys of labor input, which some previous studies suggest may matter (Nalewaik 2010 on output; Hagedorn and Manovski 2011, and Ramey 2012, on hours). We find that, despite claims in the literature, the reduced cyclicality of TFP is robust.

Second, we discuss the central role of reduced variation (and correlation with hours) of factor utilization. In the short run, variation in utilization-that is, labor effort and the

\footnotetext{
${ }^{1}$ Stiroh (2009), to the best of our knowledge, is the first paper to document this countercyclical shift during the Great Moderation period.

2 See Basu and Fernald (2001) for a broad discussion of procyclical productivity. Key recent references on the changing cyclicality include Stiroh (2009), Gordon (2010), Galí and van Rens (2014), and Barnichon (2010).
} 
workweek of capital-is a key reason why measured TFP changes do not reflect technology changes. In the Fernald data, the changes in cyclicality primarily reflect the reduced quantitative importance of procyclical factor utilization.

Indeed, after controlling for variations in factor utilization, "utilization-adjusted TFP" in the Fernald dataset is consistently countercyclical-shocks are sharply negatively correlated with changes in hours. Results are thus similar to those of Galí (1999) and Basu, Fernald, and Kimball (2006). On balance, utilization-adjusted TFP shows little change in its cyclical properties over time, apart from a brief period in the 1980s when it is acyclical with respect to hours. This brief change is somewhat consistent with Galí, López-Salido, and Vallés (2003) and Galí and Gambetti (2009). Those authors use an alternative methodology of structural VARs with longrun restrictions and find a more persistent change in cyclicality conditional on technology improvements. In New Keynesian models, the response to technology innovations depends on how monetary policy responds to them; so these authors interpret the changes as reflecting improved monetary policy. In our estimates, in contrast, the changes in the policy reaction function were less persistent-they may not have extended beyond the late 1980s transition from Volcker to Greenspan.

Third, we survey a range of stories for why productivity has changed cyclicality. Conceptually, many of the hypotheses involve changes in the cyclicality of measurement errors, either in output or in different dimensions of inputs. These include a growing role for (unobserved) intangible investments as well as reduced use of variations in factor utilization; the latter could reflect increased flexibility of the economy or else shifts away from manufacturing and toward sectors where utilization is a less important margin of adjustment. ${ }^{3}$

Reduced procyclicality of (endogenous, non-technological) factor utilization appears most responsible for TFP's diminished cyclicality. Increasing flexibility of the economy plausibly plays a role in the reduced variation in factor utilization, but the changing structure of the economy appears empirically important as well. Reduced variance of non-technological

\footnotetext{
${ }^{3}$ For the recent period, under-measured quality improvement and unmeasured digital output have been proposed as increasingly important sources of mismeasurement. These factors could, in principle, contribute to the recent weakness in measured productivity. We do not discuss this source of mismeasurement further. See Byrne et al. (2016).
} 
("demand") shocks relative to the variance of technology shocks also appears to play a key role. The reason is that technology improvements raise measured TFP but reduce inputs - creating a negative correlation. This can be partly offset by the fact that demand shocks also raise measured TFP (because of utilization) but also raise inputs. So a relative shift toward technology shocks puts more weight on shocks that generate countercyclical responses. ${ }^{4}$

In contrast, worsening mismeasurement of output, particularly the unmeasured activities devoted to intangible investment, does not seem to explain the reduction in TFP's cyclicality. But tests of this hypothesis suffer inherently from data limitations.

The reasons for earlier procyclicality, and the shift towards countercyclicality, have implications for business-cycle modeling. First, the evidence has not been kind to the original RBC view that business cycles are driven by procyclical technology shocks in a frictionless model. As already noted, technology improvements are associated with declines in inputs. Thus, the RBC interpretation did not fit the facts-even when TFP was procyclical. But it is ironic that, just as RBC models were being developed in the 1980s, TFP itself ceased to be substantially procyclical, even without any adjustments, and labor productivity turned countercyclical. ${ }^{5}$ As Francis and Ramey (2005, p. 1380) put it, “The original technology-driven real business cycle hypothesis does appear to be dead."

Second, New Keynesian dynamic stochastic general equilibrium (DSGE) models in recent decades have found that it is crucial to incorporate variations in factor utilization. As Christiano, Eichenbaum, and Evans (2005) emphasize, variable factor utilization is key to propagating shocks and fitting a variety of data. If firms can vary the intensity of factor use, then the effective supply of capital and labor becomes more elastic, which dampens changes in marginal cost. Small shocks (to

\footnotetext{
${ }^{4}$ Barnichon (2010) makes this argument.

${ }^{5}$ This does not mean that technology shocks do not matter. Basu, Fernald, Fisher, and Kimball (2013), for example, find that they do; but it also matters whether the shocks hit the consumption sector or the investment sector. Investment technology improvements are broadly contractionary, whereas consumption technology improvements are expansionary. Nevertheless, they do not find that multi-sector RBC models fit the results; they find that multisector New Keynesian models might.
} 
technology or demand) can then lead to large fluctuations. With sticky nominal prices, these elastic factor supplies help increase the persistent real effects of nominal shocks. ${ }^{6}$

Section 2 presents a brief review of the history of thought on the cyclicality of productivity. Section 3 documents the robust stylized facts about changes in cyclicality of labor productivity and conventionally measured aggregate TFP. Section 4 discusses the role of nontechnological, cyclical factors in measured aggregate TFP and highlights the role of variations in factor utilization. Section 5 uses the "facts" from Sections 3 and 4 to discuss a wide range of explanations that have been proposed. Section 6 briefly discusses the cyclicality of productivity in other countries. Section 7 concludes.

\section{Overview of the History of Thought}

At least since Mitchell (1913) a century ago, the cyclicality of productivity has been seen as a key stylized fact of business cycles. This section draws out a few high-level strands of thought that will recur later. We draw heavily on Biddle (2014) and Basu and Fernald (2001), who have further discussion.

As Biddle points out, conventional wisdom about the cyclicality of productivity has changed several times. The changing views reflect in part that the cyclicality is not pinned down a priori. As a result, it need not be constant over time but may depend on the relative magnitudes of an array of forces. These potentially include the mix of shocks that hit the economy as well as the costs associated with various margins of adjustment by firms and households.

Conventional wisdom in the first half of the $20^{\text {th }}$ century held that productivity was countercyclical-rising in recessions, falling in booms. Biddle (2014) notes that at least four arguments, based on anecdotes and a priori reasoning, supported countercyclicality: ${ }^{7}$

\footnotetext{
${ }^{6}$ A few other examples that highlight the role of variable utilization in (flexible-price as well as sticky-price) DSGE models include: Burnside, Eichenbaum, and Rebelo (1995), Bils and Cho (1994), Burnside, Eichenbaum, and Rebelo (1996) and King and Rebelo (2000). See also Smets and Wouters (2007). Barnichon (2010) discusses the changing importance of variations in factor utilization in explaining changes in the cyclicality of productivity in a DSGE setting.
} 
- Standard neoclassical theory. Suppose a firm has constant returns to scale, but that capital is fixed in the short run, whereas labor is variable. Then, as the firm responds to demand fluctuations, it runs into diminishing marginal productivity of labor. Hence, a demand-induced expansion of the economy should cause the average productivity of labor to fall.

- Labor quality varies over the business cycle: Less-skilled workers are fired in downturns. As Mitchell (1913, pp. 477-478, quoted in Biddle 2014) wrote: “Less efficient employees are the first to be discharged after a crisis. Hence the relatively small working forces of depression are the picked troops of the industrial army."

- Workers in booms may become more tired as they are asked to do more work in an expansion, leading their average productivity to fall.

- Employee motivation may vary over the cycle: "Men cannot be induced to work at so fast a pace when employment is abundant as when it is scarce"(Mitchell 1913, again as quoted in Biddle).

However, by the early 1960s, newly available data showed that, despite these intuitive arguments, productivity was, in fact, procyclical-rising in booms and falling in recessions (Hultgren 1960). Solow (1964) stressed the importance for macroeconomics of explaining the procyclicality of productivity. And, indeed, the economics literature quickly developed theories to explain the new facts. The consensus explanation was so-called "labor hoarding." Because of adjustment costs associated with hiring, firing, and training, firms chose not to fire workers during a temporary downturn (for example, Oi 1962 and Okun 1963). These costs gave much of labor cost a fixed or overhead feature.

Corresponding cyclical variations in capital utilization were also emphasized (for example, Marris 1964). Indeed, Solow's original (1957) growth-accounting paper discussed the

\footnotetext{
7 These arguments all appear in recent literature as well. The first two appear in standard growth accounting (Section 3.A): Countercyclical capital deepening and labor "quality." Lazear, Shaw, and Stanton (forthcoming) find evidence for the fourth (motivation to shirk). Burda, Genadek, and Hamermesh (2015) find some evidence for the third effect (worker exhaustion); they also find some evidence for the fourth (shirking) effect, although it is dominated by the labor-hoarding effect discussed below.
} 
need to adjust capital for "the fact of idle capacity" (p. 314). Griliches and Jorgenson (1966) and Jorgenson and Griliches (1967) explicitly considered the utilization of labor and capital. Gordon (2003) quotes Evsey Domar (in an MIT lecture of October 26, 1964) as asserting that "changes in the utilization of capital and of labor explain cyclical variations in total factor productivity." This observation has held up well over the past 50 years.

Direct evidence supported the view that, in downturns, firms retained more labor than strictly necessary. For example, Fay and Medoff (1985) surveyed firms during the 1981-1982 recession and found that, in the trough quarter, the typical firm paid for 8 percent more hours than were technologically necessary to meet current production and operational needs. Half of that labor was, in fact, engaged in productive, but nonmarketable activities, such as maintenance, cleaning, and training. The other half was unnecessary for current production and was effectively idle. These workers were kept on to avoid the cost of rehiring them when demand recovered.

The labor-hoarding explanation assumed that business cycles reflected fluctuations in aggregate demand. But in the 1980s, real-business-cycle (RBC) models provided an alternative explanation for procyclical TFP: Perhaps procyclical technology shocks were, in fact, a key driver of business cycles? Canonical RBC models (such as Kydland and Prescott 1982) with procyclical technology shocks (calibrated to observed Solow residuals) appeared to explain a range of business-cycle facts.

Of course, this raises the question of whether technology shocks are, in fact, procyclical. A large literature has built on and extended earlier insights about why non-technological factors affect measured TFP. For example, as Basu (1996), Basu and Fernald (2001), and Basu, Fernald, and Kimball (BFK 2006) make clear, measured TFP generally includes a range of nontechnological factors, from unmeasured fluctuations in resource utilization (such as labor effort 
and capital's workweek) to the effects of non-constant returns to scale or imperfect competition. We discuss these factors in Section $4 .{ }^{8}$

Empirically, non-technological factors appeared to explain the bulk of the procyclicality of TFP. Once TFP is adjusted for unmeasured changes in utilization, BFK (2006) find that positive technology shocks are actually contractionary for inputs in the short run. Galí (1999) and Francis and Ramey (2005) find a similar result in structural VARs, implying as well that non-technological influences explained the observed procyclicality of TFP. An implication is that TFP can become more or less cyclical even with constant cyclicality of true technology.

As noted in the introduction, more-recent New Keynesian models typically incorporate variable factor utilization as a key feature of the model; Christiano, Eichenbaum, and Evans (2005) discuss this point at length. The reason is that this margin of adjustment helps the model to propagate shocks and is empirically important for fitting the data. Hence, the cyclicality of productivity remains central to understanding and assessing models of business cycles.

Utilization (and variation in its importance) can also help match conditional as well as unconditional moments of the data. For example, Galí and Gambetti (2009) and Barnichon (2010) find that in the Great Moderation period, productivity had become less procyclical conditional on monetary shocks. They interpret this as a change in the flexibility of the economy and reduced use of utilization margin. Barnichon (2014) discusses how the endogeneity of productivity, arising from variable factor utilization, can explain the so-called "Shimer puzzle" (Shimer 2005) in a New Keynesian model. Gordon (2010) and Daly et al. $(2014,2015)$ discuss links to “Okun's Law."

This brief review of the history of thought highlights themes that recur below. These include the role of variable factor utilization; the fact that some forces push productivity to be procyclical and others countercyclical; and that the structure of the economic model may matter for how shocks translate into measured productivity.

\footnotetext{
${ }^{8}$ These papers built on the earlier labor hoarding literature, as well as Hall $(1988,1990)$ on increasing returns and imperfect competition. Rotemberg and Woodford (1995) discuss imperfect competition in DSGE models. A related literature explored externalities; see Caballero and Lyons (1992), Basu and Fernald (1995), and Sbordone (1997).
} 


\section{Facts, From Simple Aggregate Definitions}

With this background, we now present aggregate stylized facts about the changing cyclicality of U.S. labor and total factor productivity. These facts motivate the economic hypotheses we explore in the sections that follow. The main takeaways are:

- Labor productivity is less procyclical (or more countercyclical) than TFP. Labor productivity includes endogenous countercyclical effects of capital deepening and, to a lesser extent, labor quality. The economic stories we consider in the sections that follow are mostly about the cyclicality of TFP.

- TFP shifted from strongly to weakly procyclical with respect to labor hours after the early 1980s. Labor productivity shifted from weakly procyclical to strongly countercyclical.

- These shifts are robust to alternative data sources. The shift is less pronounced, but nonetheless large, using income-side rather than expenditure-side output data. The shift is not affected by using household versus establishment data on hours.

\section{A. Definitions}

Labor productivity and TFP can be calculated with minimal assumptions. We defer economic interpretation until Section 4. We focus on aggregates at the level of the business sector and suppress time subscripts for clarity. We denote growth in aggregate value-added as $d v$.

Labor productivity, the most basic measure, is value added per hour, $V / H$. Growth in labor productivity is then $d v-d h$. TFP goes further and measures output growth relative to a broader set of inputs. (This is the main reason why we focus our later analysis on the cyclical 
properties of TFP.) If $S_{L}$ is labor's share of income, $d k$ is growth in capital, and $d l q$ is growth in measured labor quality, ${ }^{9}$ then:

$$
d t f p \equiv d v-\left(1-s_{L}\right) d k-s_{L}(d h+d l q)
$$

We will always refer to TFP as this conventionally measured Solow residual. It follows from this definition that labor productivity growth can be expressed as:

$$
d v-d h=d t f p+\left(1-s_{L}\right)(d k-d h-d l q)+d l q
$$

Labor productivity can rise because TFP rises, because of capital deepening - if workers have more "tools" to work with (equipment, software, structures, and so forth), or because they are more educated or experienced. Note that this is an identity-it holds even if TFP does not reflect changes in technology (and, in the short run, it does not). We consider the economic meaning of TFP in Section 4.

Based on equation (2), we expect labor productivity to be more countercyclical (less procyclical) than TFP. The reason is that capital deepening and labor quality are both countercyclical. In recessions, for example, capital deepening tends to rise, since capital is relatively smooth while hours worked fall. Labor quality also tends to rise since, empirically, low-skilled workers disproportionately lose jobs in downturns.

\section{B. Quarterly Growth-Accounting Data}

To identify aggregate facts, we use quarterly growth-accounting data for the U.S. business sector from Fernald (2014a). Our dataset, which runs from 1947:Q2 through 2015:Q2, seeks to be as consistent with production theory as possible. A data appendix discusses further details, but we highlight a few points here.

\footnotetext{
${ }^{9}$ Measures of labor quality or "composition" have been standard in growth accounting since Jorgenson and Griliches (1967). The idea is that an hour worked by a neurosurgeon and a carpenter are distinct, and may have a different marginal product. Labor quality measures use relative wages to infer relative marginal products. See Bosler et al. (2015).
} 
First, in addition to standard growth-accounting terms, the Fernald (2014a) dataset has an empirical measure of factor utilization, which we discuss in Section 4. So TFP growth (defined as in equation (1)) is further decomposed into variations in utilization and in “utilization-adjusted TFP." Utilization follows BFK (2006).

Second, the default measure of output is the geometric average of the expenditure and income sides of the national accounts. Hence, labor productivity differs slightly from what the Bureau of Labor Statistics (BLS) reports; the BLS uses only the expenditure side. In principle, these two measures should be the same, but in practice they are not. Nalewaik (2010) and Aruoba et al. (2015) argue that it is preferable to use information from both sides of the accounts. Section 3.D discusses robustness to the output measure.

Third, the data cover the business sector. Little is lost by focusing on the business sector: That sector is the cyclical portion of the economy and the portion where the usual firm-level assumptions apply. Hours and employment come from the BLS productivity and cost release.

These labor data are based primarily on surveys of establishments (from the Current Establishment Survey, or CES). Section 3.D considers household data on hours and employment from the Current Population Survey (CPS).

Hagedorn and Manovskii (2011) report sizeable differences in the cyclicality of productivity, using employment from the different surveys. They claim that, using household data, labor productivity remains procyclical. We find no evidence for this claim.

Indeed, we find that it makes no difference whether one uses the household or the establishment data for hours: in either case productivity becomes less procyclical or even countercyclical. Changing cyclicality is robust across data sources. 


\section{C. Quarterly results}

Tables 1 and 2 summarize the sharp reduction in procyclicality after the mid-1980s for both labor productivity and TFP. The tables show correlations with indicators of the business cycle, using several different filters to identify the cyclical component of each series. ${ }^{10}$

Table 1a shows that, prior to 1984, labor productivity was strongly positively related to output at business-cycle frequencies. Since 1984, in contrast, labor productivity has been essentially uncorrelated with output. This substantial reduction in comovement with output is robust to identifying business-cycle frequencies using a bandpass or HP filters, or to focusing on high-frequency comovement in terms of growth rates. The final column shows that the differences are statistically significant.

Table $1 \mathrm{~b}$ shows that, with respect to hours worked (based on the CES data), labor productivity shifted from being weakly procyclical to being strongly countercyclical.

Of course, labor productivity should be more countercyclical than TFP because of capital deepening and labor quality. Table 2 confirms this expectation: TFP remains weakly procyclical with respect to both output and hours worked after 1983. But the falling correlation (that is, the reduction in procyclicality) is large and statistically significant with respect to both output (Table 2a) and hours (Table 2b).

The tables simply divide the time series in 1983. This timing coincides with the break date identified (for example, see Stock and Watson 2002) for the significant decline in the volatility of aggregate real variables such as output and investment.

Rolling correlations support this dating. Figure 1 shows 40 -quarter (that is, 10 -year) rolling correlations, which provide a more continuous measure of the change in cyclicality. We focus on the four-quarter growth-rate filter. Figure 1(a) shows that the clear break occurs in

\footnotetext{
${ }^{10}$ Interesting things could be happening at other frequencies. Cantore et al. (2014) examine the comovement of productivity with macro variables at different frequencies. Rua (2010) discusses the uses of wavelets to measure how comovement between variables across different frequencies changes over time. Gordon (2010) considers an alternative Kalman-filter "gap" approach, which also finds a significant shift in cyclicality. The growth-rate filter we mainly focus on later is natural in growth accounting (where TFP is defined in growth rates) and is easy to match to the output of models. But it does emphasize high frequencies.
} 
estimation samples that end after the early 1990s, which are samples containing data only from the early 1980s and after since we use a 10-year window to estimate the correlations.

The shifts are particularly sharp for labor productivity. In recent decades, labor productivity has had only a weak correlation with output and a substantially negative correlation with hours. TFP shifts from being strongly positively correlated with hours to being about uncorrelated with hours, particularly in samples that contain data from the mid-1980s to the mid-2000s.

Interestingly, for TFP, but much less so for labor productivity, the Great Recession partly restored the correlation with hours toward its earlier positive values. As Fernald (2014b) shows, standard TFP during and after the Great Recession was highly procyclical-it fell sharply during the recession, and then rebounded sharply. He attributes this pattern to a sharp fall and rebound in utilization, which we discuss later. Labor productivity flattened out during the recession but did not fall as much as TFP, because low-skilled workers lost jobs (so labor quality rose) and capital per employed worker also rose.

More broadly, though, Figure 1(b) shows that a wider "gap" opens up after the mid1990s (and further after 2010) between the correlations of TFP and hours, and of labor productivity and hours. In other words, the shift to countercyclicality is much more pronounced for labor productivity. This turns out to reflect the reduced variance of TFP relative to labor productivity. To see this, one can manipulate equation (2) to find:

$$
\begin{aligned}
& \operatorname{Corr}(d v-d h, d h)=\operatorname{Corr}(d t f p, d h)\left(\frac{\operatorname{std}(d t f p)}{\operatorname{std}(d v-d h)}\right) \\
& \quad+\operatorname{Corr}\left(\left(1-s_{L}\right)(d k-d h-d l q)+d l q, d h\right)\left(\frac{\operatorname{std}\left(\left(1-s_{L}\right)(d k-d h-d l q)+d l q, d h\right)}{\operatorname{std}(d v-d h)}\right)
\end{aligned}
$$

In results not shown, we find that the widening gap primarily reflects that the standard deviation of TFP relative to that of labor productivity $(d v-d h)$ has fallen. This effectively reduces the weight on the first term $\operatorname{Corr}(d t f p, d h)$. Conversely, it increases the effective weight of countercyclical capital deepening and labor quality (the second line).

That is, reduced volatility of TFP itself (which we later link to reduced volatility of utilization) largely "explains" why the shift in cyclicality is larger for labor productivity than for 
TFP. This is another reason why, in what follows, we focus on understanding changes in the cyclicality of TFP.

\section{D. Robustness to Measurement of Output and Hours}

Do the "facts" about changing cyclicality depend on the measures of output or labor hours used? In this subsection, we find that the changes identified in 3.C are robust.

Nalewaik (2010) finds that the income side of the U.S. national accounts has additional information about the business cycle over and above that reported in the more standard expenditure-side measures. Here, we look at the income and expenditure sides separately, rather than averaging them (as was done in Table 1 and Table 2, and Figure 1). ${ }^{11}$

Hagedorn and Manovskii (2011) and Ramey (2012) suggest that results on the changing cyclicality of productivity are sensitive to the choice of hours measures. Productivity measurement at the BLS and elsewhere has relied primarily on establishment data (from the CES), which are usually considered more reliable. But the BLS produces an alternative "household" measure, from the household, or CPS, survey.

In contrast to these claims, we find that results are robust. We constructed four alternative measures of business-sector TFP, which mix the two measures of output (income side and expenditure side) with the two different measures of hours worked. (As a reminder, the measures reported earlier took the geometric average of income and expenditure, and used the establishment/CES measure of hours.)

In terms of hours, it is important to account for the fact that the coverage of the surveys differs. The household survey covers the entire civilian economy, which is broader than the business sector reported in the productivity release (which, in turn, is based primarily on the establishment survey). The appendix describes how we convert household-survey hours from the civilian economy to the business sector: in short, we subtract BLS estimates of non-business hours. (The appendix also discusses the strengths and weaknesses of the two surveys.)

\footnotetext{
${ }^{11}$ We also considered the Kalman-filter measure from Aruoba et al. (2015). Although TFP was less volatile with this measure, the rolling correlations below were by and large consistent with the changes based on the income- and expenditure-based measures.
} 
Figure 2 shows rolling correlations for the four alternative measures. The broad patterns are similar for all the measures. Panel (a) shows correlations with output. The reduction in the correlation in samples ending after the early 1990s is somewhat larger for the expenditure side than for the income side. But the latter reduction is nevertheless large and statistically significant.

Figure 2(a) also shows that it makes virtually no difference whether one uses the CES or the CPS hours - the lines are qualitatively very similar. Using expenditure measures of output, the CES hours series implies a little larger drop in correlation than the CPS hours series. But using income measures of output, the opposite is true-the drop in correlation is larger with the CPS. The important point is that the patterns and magnitudes are the same.

Figure 2(b) and 2(c) show the corresponding correlations with hours worked. Panel (b) uses CES hours; Panel (c) uses CPS hours. Again, qualitatively, they show little difference. TFP shifted from being strongly procyclical to being acyclical or even countercyclical from the mid1980s to the mid-2000s. As we saw before, of course, samples that include the Great Recession show more procyclicality of TFP with respect to hours than with respect to employment. (Measurement error mechanically leads the correlation with CES hours in Panel (b) to be more negative if TFP is also calculated with CES hours, and similarly in Panel (c) with CPS hours.)

Our results contrast with those of Hagedorn and Manovskii's (2011). The reason is that they construct their measure of household-survey (CPS)-based productivity incorrectly. They calculate CPS-based productivity using non-farm business output in the numerator and totalcivilian-economy employment (not hours) in the denominator (see notes to their Table 1, page 607). (With this incorrect definition, we can replicate their (spurious) finding that labor productivity appears to remain procyclical.)

The Hagedorn and Manovskii (2011) definition has two problems. First, the business sector is cyclical, whereas the non-business sector is not. Hence, their numerator is inherently more procyclical than their denominator. It is important to be consistent in coverage of the economy. Second, they ignore hours per worker. As Daly et al. (2015) report, not only are hours per worker more cyclical in the CPS than in the CES, but the difference grows over time. The differences arise because some individuals have multiple jobs. Multiple-job-holding is 
procyclical. Hence, "bodies" are more cyclical in the establishment survey, but that is offset by the increased cyclicality of hours per person in the household survey. For productivity measurement, what matters is total hours - the product of bodies and hours per person. Cyclical movements in total hours are similar in the two surveys, so the choice of survey makes little difference

Finally, although not shown, we note that there was a larger change in the magnitude of the correlations for the business sector than for the overall economy. Output and employment in the business sector, which is three-fourths of the economy, have always been more cyclical than in the government, household, and non-profit sectors. But the differences have grown.

Figure 3 shows that, over time, both output and employment in the non-business sector have become increasingly negatively correlated with business hours. Possibly the non-business sector (such as government) has become countercyclical as a risk-sharing/insurance/stabilizing response to the increasing flexibility of the business sector. This is especially true of nonbusiness employment (and hours, not shown). The non-business sector's "stabilizer" role manifests more during downturns: its employment growth tends to remain positive, while business employment falls substantially.

These changes in the non-business sector do not affect our main takeaway from this section that the shifting correlations are a robust feature of the data. Since the 1980s, businesssector TFP has become less procyclical, while labor productivity has turned countercyclical.

\section{The Important Role of Non-Technological, Cyclical Factors in TFP}

So far, we have documented facts about labor productivity and TFP. Although TFP growth measures technology change under standard conditions, those conditions do not hold in the short run. A quantitatively important reason is variations in factor utilization-namely, labor effort and the workweek of capital.

To see how these considerations influence the observed changes in correlations, we need

to specify the margins of adjustment available to firms, and how decisions at a firm (or 
industry) level aggregate to the economy-wide level. We do so following BFK (2006) and Basu and Fernald (2001). ${ }^{12}$

\section{A. Industry and Aggregate Technology}

We assume each industry has a production function for gross output:

$$
Y_{i}=F^{i}\left(A_{i} K_{i}, E_{i} H_{i} N_{i}, M_{i}, Z_{i}\right)
$$

The industry produces gross output, $Y_{i}$, using the capital stock $K_{i}$, employees $N_{i}$, and intermediate inputs of energy and materials $M_{i}$. As in the factor-hoarding literature, the capital stock and number of employees are quasi-fixed, so their levels cannot be changed costlessly. But industries may vary the intensity with which they use these quasi-fixed inputs: $H_{i}$ is hours worked per employee; $E_{i}$ is the effort of, each worker; and $A_{i}$ is the capital utilization rate (that is, capital's workweek). Total labor input, $L_{i}$, is the product $E_{i} H_{i} N_{i}$. (We abstract here from heterogeneity in worker types and variations in labor quality, $d l q$, discussed in Section 3.A.)

The production function $F^{i}$ is (locally) homogeneous of arbitrary degree $\gamma_{i}$ in total inputs. $\gamma_{i}>1$ implies increasing returns to scale, reflecting overhead costs, decreasing marginal

cost, or both. $Z_{i}$ indexes technology. (Note: We use a $\sim$ for variables that may be defined slightly differently, possibly in terms of scaling, in the gross-output industry production function from their aggregate value-added counterparts. For our purposes, the distinctions are not important.)

Following Hall (1990), we assume cost minimization and relate output growth to the growth rate of inputs. The standard first-order conditions give the necessary output elasticities, that is, the weights on growth of each input. ${ }^{13}$ Let $d x_{i}$ be observed input growth, and $d u_{i}$ be

12 Those papers have detailed derivations and additional references. ${ }^{13}$ With increasing returns, firms must charge a markup of price over marginal cost to cover their total costs. Hence, the resulting equation controls for imperfect competition as well as increasing returns. 
unobserved growth in utilization. (For any variable $J$, we define $d j$ as its logarithmic growth rate $\ln \left(J_{t} / J_{t-1}\right)$.) This yields:

$$
d y_{i}=\gamma_{i}\left(d x_{i}+d u_{i}\right)+d z_{i}
$$

where

$$
\begin{gathered}
d x_{i}=s_{K i} d k_{i}+s_{L i}\left(d n_{i}+d h_{i}\right)+s_{M i} d m_{i}, \\
d u_{i}=s_{K i} d a_{i}+s_{L i} d e_{i},
\end{gathered}
$$

and $S_{J i}$ is the ratio of payments to input $J$ in total cost.

With constant returns, perfect competition, and no utilization changes, technology change $d z_{i}$ equals the standard (gross-output) Solow residual (TFP): $d z_{i}=d t f p=d y_{i}-d x_{i}$.

Implementing equation (4) requires estimating the (not directly observed) utilization term as well as the $\gamma_{i}$. To do so, BFK wrote down a dynamic cost-minimizing model of the firm where labor and capital are quasi-fixed. If the firm wants more input in the short run, it can adjust an observable intensity margin of hours per worker or unobserved intensity margins of labor effort and the workweek of capital. The first-order conditions imply that the firm uses all margins simultaneously. ${ }^{14}$

Hence, observable hours per worker can proxy for unobservable utilization margins. BFK estimate the parameters, allowing different parameters across industries. See BFK (2006) for details.

At the aggregate level, TFP can differ from technology not only because of unmeasured input components but also because of reallocations. That is, the efficiency of resource allocation may vary over time due to frictions in output or input markets that preclude perfect mobility of

\footnotetext{
14 The derivation assumes that the cost of varying capital's workweek is a shift premium, as documented by Shapiro (1993, 1996). See Basu and Kimball (1997) for more discussion.
} 
resources across firms or industries. Specifically, the relationship between aggregate TFP (dtfp) and aggregate technology $\left(\mathrm{dz}_{t}\right)$ can be expressed as: ${ }^{15}$

$$
\mathrm{d} t f p_{t}=(\bar{\gamma}-1) \mathrm{d} x_{t}+\mathrm{d} \bar{u}_{t}+R+\mathrm{d} z_{t}
$$

where $d t f p$ is growth of aggregate (value-added) TFP, as in Section 3.A; $d x_{t}$ is the measured primary inputs of aggregate capital and labor, $\left(1-s_{L}\right) d k+s_{L}(d h+d n)$; and $d z$ is aggregate technical change. $\bar{\gamma}$ is the (VA-weighted) average of gross-output returns to scale. $\mathrm{d} \bar{u}_{t}$ denotes the appropriately weighted average contribution from unmeasured inputs.

$R$ denotes various "reallocation" effects. These are the growth-accounting counterpart to the wedges discussed in the misallocation literature (see Fernald and Neiman 2011, for discussion of the links). Those reallocation terms arise from differences in returns-to-scale or differences in factor prices across firms, which imply that the value of the marginal product of capital or labor might differ across firms.

Because of limitations with quarterly data, Fernald (2014a) assumes that all firms produce with constant returns to scale, are perfectly competitive, and pay the same factor prices. The reallocation terms then all disappear. TFP growth depends solely on variations in utilization and on growth in "utilization-adjusted TFP":

$$
\mathrm{d} t f p_{t}=\mathrm{d} \bar{u}_{t}+\mathrm{d} z_{t} .
$$

These are strong assumptions. Still, Basu and Fernald (1997) find that deviations from constant returns are relatively modest (although they do matter, especially in durables); and Basu, Fernald, Fisher, and Kimball (2013) find that, even in the short run, utilization is the main wedge between TFP and technology. However, Wang (2014) finds evidence that reallocations $R$, including those related to differences in returns to scale across industries, could be quantitatively important.

\footnotetext{
${ }^{15}$ See Basu and Fernald $(2001,2002)$ for derivations. They show slightly different arrangements of this identity; but, since the empirical work in Section 4.B abstracts from increasing returns and reallocations, the differences do not matter. Some of these reallocation (or "misallocation") effects appear earlier in a growth-accounting context in, for example, Jorgenson, Gollop, and Fraumini (1987) and Basu and Fernald (1997).
} 
Thus, it is worth keeping in mind that TFP adjusted for utilization using aggregate data (such as in Fernald 2014a) is not necessarily a "fully purified" Solow residual. Some measurement error surely remains. This error potentially gives rise to reallocation effects that will be part of such utilization-adjusted TFP series.

\section{B. Changing cyclicality of utilization and utilization-adjusted TFP}

Fernald (2014a) provides quarterly estimates of utilization and utilization-adjusted TFP. We now present rolling correlations similar to those we showed earlier.

Figure 4 (a) shows that utilization-adjusted TFP has, by and large, been consistently negatively correlated with inputs throughout the post-war period. The correlation with output has more often been weakly positive since the late 1980s, but more often negative before and in recent years. There is a brief period, in samples ending roughly from 1985 to 1990, when the correlation with inputs turned positive. That brief change is consistent with the findings in Galí, López-Salido, and Vallés (2003) and Galí and Gambetti (2009). ${ }^{16}$ But according to the BFK/Fernald identification, that change did not last.

So according to this evidence, technology as measured by utilization-adjusted TFP is always a force for countercyclicality with respect to inputs. Why, then, did TFP (but not utilization-adjusted TFP) change cyclicality? The answer is that utilization became less important.

Figure $4(\mathrm{~b})$ shows that utilization became less correlated with hours over time. The changes did not appear to last, as the correlation rebounds in samples that end after the mid1990s. However, the correlation alone does not capture the declining role of utilization. Figure 5 plots rolling standard deviations. The volatility of utilization-adjusted TFP growth shows little trend over time. But the volatility of utilization growth - and, with it, TFP growth - fell sharply since the 1980s.

\footnotetext{
16 A conceptual difference is that the long-run restriction identification focuses on permanent technology changes, whereas the growth-accounting methods also include transitory changes.
} 
Have dynamic responses of the business sector to technology shocks shown important changes? Figure 6 plots impulse responses to a 1-percent increase in utilization-adjusted TFP. Responses are estimated separately for the period before 1984 (1950:Q1 to 1983:Q4) and after 1983 (1984:Q1-2015:Q2). ${ }^{17}$ The largest differences in responses appear on impact.

Panel (a) shows that average weekly hours fall on impact in both subsamples; the magnitude of the decline is about one-third smaller in the post-1984 period. By comparison, utilization (panel b) contracts on impact by much more (twice as much) before 1984; the difference across subsamples is statistically significant. (The apparent discrepancy between hours per worker and utilization stems from changing sectoral composition of the economy, as we discuss later).

Panel (c) shows that after 1983 employment has gone from contracting slightly to registering basically no change in response to a positive technology impulse.

The increased use of hours per worker relative to employment as the margin of adjustment is consistent with the hypothesis that the persistence of technology shocks may have risen (Wang 2014); this will be discussed further in the next section. At the same time, the fact that hours per worker contracts less is consistent with the thesis of Galí, López-Salido, and Vallés (2003) that monetary policy became somewhat more adept at accommodating technology shocks by raising demand. Hence, firms need not scale back inputs as much. Consistent with this interpretation, output (Panel d) indeed rises significantly more when technology improves. Before 1984, output stayed put, statistically speaking, when technology rose; after 1983, the increase in output became significant. These impulse responses imply that the pattern of the post-1983 change in the responses of labor productivity and TFP (not shown) are qualitatively the same as those of output: both rise by more contemporaneously when technology improves.

\footnotetext{
17 The impulse responses are estimated using a bivariate VAR with that variable and utilization-adjusted TFP, with the latter treated as the proxy for technology and thus contemporaneously exogenous. But it is allowed to respond to lags of the other variable. Eight lags of both variables are included.
} 


\section{Why Has Productivity Changed Cyclicality? Hypotheses and Evidence}

We now discuss a range of hypotheses for why the cyclicality of aggregate productivity has changed, as documented in Sections 3 and 4. The key "facts" to explain are, first, that reduced variation in utilization is a key reason why TFP has become less volatile and procyclical. Second, the response of the economy to a technology shock (identified as utilization-adjusted TFP) does not appear to have changed qualitatively. Third, the volatility of utilization-adjusted TFP has not changed much, either. Some of the stories explain these facts directly; others suggest that the aggregate variables might still suffer measurement error.

\section{A. Hypotheses to Explain the Vanishing Procyclicality}

We briefly summarize stories proposed in recent literature. The next section considers evidence, or the lack thereof, regarding them.

Some proposed stories are relatively "mechanical" in that the direct problem is some form of measurement error, where the cyclical properties of the errors might have changed. In those stories, the cyclicality of productivity would not have changed if all inputs and output had been measured accurately. Of course, the reasons for the changing measurement error may be deeper structural or institutional changes such as changes in labor market flexibility. Other stories are more subtly related to the workings of the economy, such as the type and persistence of technology or demand shocks, and the conduct of monetary policy.

"Mechanical" explanations include: 1) more-flexible labor markets and thus less need to adjust the unobserved intensity margin; 2) fewer procyclical reallocations; 3) shifts in the structure of the economy; and 4) increased importance of intangible investment in firms' overall output.

First, if labor markets have become more flexible, so that it is now less costly to adjust the extensive margin (number of workers), then firms may rely less on adjusting intensive margins of production (including both observed hours per worker and unobserved labor effort) 
and more on adjusting the number of employees. ${ }^{18}$ Galí and van Rens (2014) advance this story. They argue that, given convex costs of labor-force adjustment (as in Oi 1962), reduced labor turnover has led endogenously to increased flexibility. (See also Nucci and Riggi 2009). A different manifestation of increased flexibility is that firms may be able to lay off workers more selectively during downturns so that they retain those with relatively higher productivity. Berger (2012) suggests that this can explain both the good performance of labor productivity in recessions and the slow recovery of employment afterward. ${ }^{19}$

Second, as Section 4 discussed, aggregate TFP depends on the allocation of resources across production units if they have different marginal products. If these reallocation effects, $R$ in equation (5), now fluctuate less positively with the level of activity, then their contribution to aggregate TFP becomes less procyclical as well. Relatively more reallocation during downturns can be yet another consequence of greater flexibility in labor markets, and probably capital and product markets as well, in that the need for adjustments may be greater and hence the frictions more binding during recessions.

These effects are, in principle, included in utilization-adjusted TFP, whose cyclicality exhibits little change. They are thus unlikely to be the main reason why TFP has become less procyclical. But, conceptually, reallocations are distinct from technology, and it is useful to keep them distinct. This suggests that building from the bottom up using industry or firm data could give a somewhat different answer than the top-down Fernald (2014a) measure.

Third, the shrinking share of manufacturing relative to services has likely also contributed to diminished cyclicality of productivity. Variations in factor utilization are more important in goods industries-especially durable goods industries-than in services industries. Moreover, even if all inputs were properly measured, the degree of returns to scale could matter. Durable goods exhibit more evidence of increasing returns, which further boosts

\footnotetext{
${ }_{18}$ Note that what is needed is for the cost of adjusting employment to fall more than the cost of adjusting average hours. It is quite plausible that both costs have declined. Moreover, firing costs have plausibly fallen more than hiring costs; high firing costs in expectations also deter current hiring.

${ }^{19}$ Although our TFP data control for observable labor "quality," such measures can only control for the average effect of observables such as age and education. Firms presumably know much more about their workers, so unobserved labor quality might rise in recessions.
} 
the positive correlation between TFP and inputs and output. So the diminishing share of durables reduces the contribution to utilization-adjusted TFP from this channel as well.

Fourth, just as unmeasured inputs can affect the cyclicality of TFP, so can unmeasured output. More broadly, intangible investments are a prime example. Firms undertake considerable expenditures, such as research and development or organizational restructuring, in the expectation that they will obtain future gains (see Corrado et al. 2006, for discussion).

Conceptually, we can think of the production function (3) as generating a composite output, only a portion of which is measured. The rest (the intangible investment) is not. (Inputs are also mismeasured, since the accumulated knowledge and organizational capital belong in the list of (capital) inputs but are not observed). Over time, unmeasured investments in R\&D and other intangible output have become more important (Corrado et al. 2006). McGrattan and Prescott $(2007,2012)$ propose that this unmeasured output is procyclical, so that "true productivity" is as cyclical as previously. (On the other hand, unmeasured output can also be countercyclical. For example, Fay and Medoff (1985) found that "excess" workers perform maintenance or undergo training in downturns.)

Arguments that are less mechanical and more "structural" involve changes in the mix or cyclical properties of shocks, or how agents respond to shocks, or a combination of these. For example, it is natural to expect monetary shocks (or other demand shocks) to have different effects from technology shocks. After all, as noted in Section 2, the "puzzle" of procyclical productivity in the 1960s arose because of the assumption that business cycles reflected demand shocks - and so, in booms, labor should run into diminishing returns. By contrast, RBC models assumed that procyclical technology shocks drove the business cycle.

These less-direct and more structural stories typically (although not always) need to be told with a formal model. For example, in New Keynesian models, the response of the economy to technology or other shocks depends in part on how monetary policy responds. Galí (1999) and BFK (2006) find that technology improvements have historically led to reductions in inputs for a time-suggesting that monetary policy may not have responded aggressively enough to allow actual output to rise as much as potential (flexible price) output. 
Specific hypotheses that point to changing mix and properties of shocks and policy reaction to explain the diminished cyclicality of measured productivity include: i) good luck, owing to more moderate (demand) shocks, ii) good (monetary) policy that reacts adequately to shocks (and is not itself a major source of shocks), and iii) changed nature of shocks, in particular, more persistent technology shocks.

Barnichon (2010) and Galí and Gambetti (2009) provide evidence that the mix of shocks may have changed. In particular, demand shocks have become less volatile relative to technology shocks. Empirically, technology improvements raise measured TFP but cause hours

to contract in the short run. Hence, the greater importance of technology shocks means that measured TFP should track technology more closely, and, correspondingly, comove less positively with inputs and output.

In addition, Galí, López-Salido, and Vallés (2003) argue that monetary policy became more accommodative of technology shocks after the early 1980s. If monetary policy responds adequately, then firms can react optimally (and increase production) when technology improves instead of having to cut hours-along with effort and capital's workweek-because their output is constrained due to nominal rigidities. Barnichon (2010) provides further evidence of this.

By itself, the more-flexible-labor story implies a relative increase in the variation of employment compared with the variation of hours per worker. However, data for many industries indicate otherwise (Wang 2014). To reconcile these facts, Wang (2014) suggests that technology shocks have become more persistent. Firms thus resort more to cutting hours per worker than to cutting payroll following a good technology surprise, leading to the greater use of the observed intensive margin relative to the extensive margin.

\section{B. Some Evidence on the Proposed Hypotheses}

We now review some of the empirical evidence for the explanations above. An obvious hypothesis is that the response of the economy to a technology shock may have changed. But Section 4.B found little evidence of that. So we need to look elsewhere. 
Rather, we need to understand why there is less variation in factor utilization over the business cycle. Increased flexibility of the economy plausibly plays some role in this reduction, but the changing structure of the economy appears important as well. Some evidence suggests that there may be modestly diminished procyclicality of reallocations. In contrast, there is little evidence in available data to support a role for intangible investment in lowering the procyclicality of TFP.

There is also evidence that demand shocks have contributed less to output fluctuations than technology shocks in recent decades, and the nature of the shocks may have changed as

well. In particular, technology growth may have become more persistent. As a result, firms may rely more on the intensive (hours per worker) margin relative to the extensive (employment) margin, despite increases in the flexibility of the economy.

\section{More-Flexible Institutions and Less Procyclical Utilization}

A plausible explanation for reduced variation in factor utilization is that the economy has become more flexible (Galí and van Rens 2014). As a result, firms have relied more on observable variation in "bodies" and less on unobserved intensity (specifically effort) measures, because various labor market changes have made it easier for firms to hire and especially fire employees. This reduces the countercyclical measurement error in labor input and in turn the procyclicality of TFP as well as LP.

A clear implication of the more-flexible-labor story is that employment should become more variable relative to intensive margins of labor adjustment. A natural test of this hypothesis is thus to compare the volatility of employment to the observed intensity margin of hours per worker. Wang (2014) examines industry data on this. In contrast to the flexibility hypothesis, she finds that employment has become less, rather than more, volatile relative to hours per worker. This is true not only with regard to unconditional volatility, but also conditional on technology shocks (see Figure 6).

We return to this point below. But it is not clear that increased flexibility alone is enough to explain the facts. 


\section{Reallocation Effects}

Section 4 discussed how, at the aggregate level, various reallocation effects $(R)$ can cause TFP to differ from technology. If frictions that impede the efficient allocation of resources across sectors used to rise during downturns, but have become less countercyclical since the mid1980s, then less procyclical reallocation could explain less-cyclical aggregate productivity. Greater labor flexibility could facilitate a relative increase in reallocation during recessions,. Deeper financial markets could also facilitate capital reallocation

Reallocation effects show up in utilization-adjusted TFP, so it is possible that bottom-up measures look different from the top-down Fernald (2014a) measures. Wang (2014) uses industry data to explore this issue. In some specifications, reallocation contributes little to reduced procyclicality; in others, it contributes more. We leave the inconsistencies for future research. Nevertheless, as shown in Section 4, Wang finds that reduced variation in utilization is a central factor.

Note that within-industry reallocations are already reflected in industry TFP and utilization-adjusted TFP. Studies using establishment-level data (for example, Foster, Haltiwanger, and Krizan 2001 and 2006) show that reallocation within industries dwarfs reallocation across industries. ${ }^{20} \mathrm{It}$ is, however, yet to be established how much the cyclicality of intra-industry reallocation has changed.

\section{Shifting Structure of the Economy}

Wang (2014) addresses the puzzle noted earlier that industry hours per worker have not become less volatile relative to employment, whereas aggregate utilization has. To the first order, changes in utilization should be proportional to changes in average hours per worker at the firm or industry level. But empirically, BFK (2006) and Wang (2014) find that this "multiple" differs across industries. Manufacturing industries, especially those that manufacture durables,

\footnotetext{
${ }^{20}$ Garin, Pries, and Sims (2013) propose a related explanation. They argue that, because of the smaller variance of aggregate shocks during the Great Moderation, reallocation shocks become relatively more important. There is thus more positive reallocation across micro units during downturns, boosting aggregate TFP.
} 
have a higher multiple on average than service industries. The declining share of manufacturing means that the decline in variability of utilization is larger at an economy-wide level than within individual industries. Wang (2014) shows that this explains why the contribution of utilization to fluctuations in aggregate output has fallen more than the contribution of raw fluctuations in average hours per worker. That said, changes in sectoral composition are too gradual to explain the timing of the precipitous fall in productivity's cyclicality around the mid1980s.

Another implication of the rising share of services is that increasing returns become a less important factor in generating procyclical aggregate TFP. Durable goods industries have more evidence of increasing returns than nondurables or services (Basu and Fernald 1997). So the shrinking share of durables reduces the effect of increasing returns on the cyclicality of productivity.

\section{Intangibles and Other Output Mismeasurement}

McGrattan and Prescott $(2007,2012)$ propose that procyclical measurement error in output has increased. Broadly defined research and development (R\&D) is poorly measured in general. If these proyclical activities have become more important, then this lowers the correlation between observed productivity and observed inputs, all else being equal.

McGrattan and Prescott $(2007,2012)$ do not address the timing of the increase in intangible investment. Why have firms boosted their engagement in activities that enhance future earnings power but do not generate current marketable output, since the mid-1980s?

Wang (2014) suggests that a reason for greater (broadly defined) R\&D activities since the mid-1980s is the growing importance of information and communications technology (ICT). To take full advantage of this new "general purpose technology" (Helpman and Trajtenberg 1998), firms have to devote resources to reoptimizing their production process. A number of studies (see, for example, Brynjolfsson and Hitt 2000, Brynjolfsson and Hitt 2003, and Oliner et al. 2007) find that benefiting from the new information-management capabilities requires reorganizing and restructuring-much of which is likely unmeasured and thus not counted as investment. 
There is, plausibly, a high degree of complementarity between investing in tangible ICT equipment and software, and investing in intangible restructuring. Basu et al. (2004) propose using this complementarity between tangible and intangible ICT-related investment to infer the latter.

As appealing as the ICT-based explanation sounds, Wang (2014) finds little evidence that this mechanism explains the declining cyclicality of productivity. There is no discernable relationship between an industry's intensity of observed ICT investment and the decline in the cyclicality of its TFP growth. On the other hand, it is also clear that, because of the intrinsic difficulty of measuring intangible investment, better data are needed to gain a more accurate

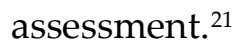

\section{Changes in the Mix of Shocks}

Galí and Gambetti (2009), Barnichon (2010), and Wang (2014) find that a decline in the importance of demand relative to technology shocks can account for a substantial fraction of the decline in the procyclicality of productivity. Because demand shocks cause procyclical movements in utilization, their reduced importance also influences the variability of utilization.

Barnichon (2010) estimates a search model of unemployment with nominal rigidity and variable labor effort. To fully account for the change in the cyclicality of labor productivity, Barnichon's (2010) model also needs greater flexibility to adjust hours per worker so that firms make less use of the effort margin. Barnichon's (2010) model is also silent on possible changes in the persistence of shocks and hence on the change in the relative volatility between hours per worker and employment.

Wang (2014) finds that technology shocks by themselves are enough to yield a negative correlation between TFP and labor input. Throughout the sample period, an improvement in technology causes hours to fall initially. Hence, the more technology shocks account for the variation in TFP, the less positive (or more negative) is the correlation of TFP with inputs. She

${ }^{21}$ Corrado et al. (2014) extend Corrado et al.'s (2006) methods to industry data. These might not capture all aspects of intangibles and, as of this writing, extend back only to 1995. 
finds that technology shocks indeed account for a greater fraction of the overall variation in TFP after the mid-1980s than previously, consistent with Barnichon (2010) and Galí and Gambetti (2009).

\section{Change in the Property of Shocks}

Wang (2014) posits that a rise in the persistence of technology shocks relative to other shocks can explain the observed rise in the relative volatility of hours per worker versus employment. ${ }^{22}$ The reason is that the relative use of extensive versus intensive labor margins depends on the persistence of shocks. Empirically, technical change is contractionary in the short run but expansionary in the long run. So, firms initially cut labor hours following an improvement in technology, even though they will want to increase hours eventually. If technology shocks become more persistent, firms know with greater confidence that they will need to increase labor hours in the future. It is thus optimal for firms to initially cut average hours per worker rather than laying off workers they will want in the future. This is consistent with the observation that hours per worker have become more volatile than employment.

Note that the comparison here is relative, not absolute. An absolute increase in the use of intensive margins by itself would imply more variable utilization and hence higher correlation between TFP and inputs. Instead, as reported in the previous section, both utilization and, to a lesser degree, employment contract less when technology improves. Also, lower persistence of demand shocks is an alternative change that can raise the variation in hours worked per worker relative to variation in the number of workers. ${ }^{23}$ This may be a contributing factor to the relative decline in the variance of demand shocks vis-à-vis technology shocks. So it seems that changing persistence of either type of shocks may help to explain the observed change in the relative variance of intensive versus extensive labor margins.

\footnotetext{
${ }^{22}$ This increase in persistence is not apparent in the Fernald (2014a) quarterly measure of utilization-adjusted TFP. But Wang's measure is somewhat different, in that it uses only expenditure-side data for output and includes additional adjustments of reallocation effects and returns to scale, using industry level annual data.

${ }^{23}$ Ramey and Vine (2006) show that less-persistent innovations in demand can explain why overtime hours (an intensive margin) have become a more important margin for adjustment than the number of shifts (an extensive margin) in the automobile industry.
} 


\section{What Happened Outside the United States?}

Our analysis has focused on the United States. A clear question is whether similar changing patterns are also visible in other countries and whether the same stories apply. The evidence is mixed, and we leave the answers for future research.

Daly et al. (2011) find some evidence that the United States has not been alone. Using rolling correlations of labor productivity growth and changes in the unemployment rate, they find that the median count of 14 advanced economies shifted from having somewhat procyclical productivity to having somewhat countercyclical labor productivity (with respect to unemployment) after the mid-1980s.

However, Berger (2012) looks at correlations of labor productivity and output, and finds that declining procyclicality is much more pronounced in the United States than elsewhere. Daula and Kay (2014) consider a broad set of countries, and several different methods. They show that there is substantial heterogeneity across countries in terms of changing cyclicality. (The heterogeneity does not seem to be related to the evolution of labor market institutions, in contrast to the implications of Galí and van Rens 2014.)

Burda and Hunt (2011) find that recent shifts in Germany run contrary to the U.S. experience. Historically, German labor productivity has been strongly countercyclical-rising in recessions over the period from 1973 to 2005. They find that the Great Recession was anomalous, in that it was the first recession where productivity fell and, thus, was procyclical. Gordon (2011) considers an EU aggregate, and also finds that, over time, productivity has become more procyclical. ${ }^{24}$

In sum, there is more work to be done for other countries. A challenge is the lack of comparable high-frequency growth-accounting data for other countries. But the range of institutional features may allow greater insight into the relevance of different stories.

\footnotetext{
${ }^{24}$ Inklaar (2007) found that at the industry level, unmeasured input utilization does not explain the procyclicality of services industries' productivity in France, Germany, and the Netherlands.
} 


\section{Conclusions}

The correlations of both TFP and labor productivity with output and inputs have declined substantially since the mid-1980s. These changes in cyclicality are robust to alternative measures of output and labor inputs.

We identify reduced procyclicality and variance of (endogenous, non-technological) factor utilization as the proximate source of TFP's diminished cyclicality. Indeed, variations in factor utilization are, empirically, the only source of procyclicality with respect to inputs. After adjusting for utilization, the response of the economy to changes in technology has been more or less consistently countercyclical. The one exception appears to have been during the Volcker period, when technology improvements tended to be (weakly) associated with increases in inputs.

It appears that increased flexibility of labor market institutions has likely played a role.

But the industry evidence does not suggest much reduced use of hours per worker relative to employment - which one would expect to find under this story. This suggests a role for changes in the persistence of different kinds of shocks as well as the evolving sectoral composition of the economy.

At a deeper level, there is evidence that technology shocks have come to account for a greater share of the variation in output and input than non-technology shocks. This leads to lower correlation between TFP and output and input because technology shocks cause (labor) input to contract in the short run. On the other hand, both the extensive and the intensive labor margin now contract less in response to a positive technology impulse. This is consistent with the notion that monetary policy now does a better job than previously of accommodating technology shocks, although it still does not do so fully.

There are a number of open questions. In terms of modeling, quantitative models can sharpen our understanding of how the different forces interact to account for the observed changes in dynamics. Such models can also examine whether and, if so, how the reduced role of factor utilization influences the propagation of shocks in the economy. 
Given the central role of less-variable utilization in accounting for the change in TFP's cyclicality - as well as its role as a propagation mechanism in DSGE models - it is important to deepen our understanding of this margin. For example, which is the more important margin of utilization - capital or labor - and how have these changed? The BFK (2006) measure uses the same proxy to infer both margins. Although Basu and Kimball (1997) suggest ways to distinguish between them, empirical estimates have failed to distinguish the two margins sharply. Recent research suggests the possibility of new direct measures. Data from time-use surveys (such as in Burda et al. 2015) and studies of companies (as in Lazear et al. forthcoming) provide direct measures of worker effort; Gorodnichenko and Shapiro (2011) improve direct measures of capital's workweek.

Along the lines of better data, it is imperative to pursue more-granular data that also cover a broader range of activities in order to construct more-accurate estimates of intangible investment. On a related note, more comprehensive data on productive activities, whether explicitly priced, should help researchers to gauge whether output underestimation is an important reason for the apparent productivity slowdown in recent years. Better measures of output quality and varieties, which have likely become more challenging to develop as the share of services in the economy has grown, are also key to understanding whether mismeasurement of output has played a role more generally. 


\section{Data Appendix}

\section{Appendix.A.Quarterly TFP data (Fernald 2014a)}

Data run from 1947:Q2 through 2015:Q2. The vintage of data used in this paper was August 11, 2015 (downloaded from

http://www.frbsf.org/economicresearch/economists/jfernald/quarterly tfp.xls). The dataset includes quarterly growth-accounting measures for the business sector, including output, hours worked, labor quality (or composition), capital input, and total factor productivity. Output is a geometric average from the income and expenditures sides of the national accounts; the two measures are both included in the dataset. Factor utilization follows Basu, Fernald, and Kimball (2006) and Basu, Fernald, Fisher, and Kimball (2013).

\section{Appendix.B. Household Survey Data on Hours}

Our main source of data on business-sector employment and hours is the Bureau of Labor Statistics (BLS) productivity and cost release. Those data, in turn, come primarily from the monthly BLS establishment survey. But the BLS also surveys households each month. The household survey has information on employment and hours worked as reported by households. These data on "persons at work" and "hours at work" adjust the headline civilian employment figures for vacations and leaves of absence. The BLS currently publishes these data only back to 1976.25 But Cociuba, Prescott, and Ueberfeldt (2012) have used hard copies of pre1976 BLS publications to extend the data back to 1948. We use their raw data on non-seasonally adjusted persons at work and hours at work in the civilian economy. ${ }^{26}$

When comparing the household and establishment surveys, it is important to be consistent in coverage: The household data cover the total civilian economy, whereas the

\footnotetext{
${ }^{25}$ We obtained these data from Haver Analytics. Hours worked is the product of variables LENCLWHN@USECON and LENCLWN@USECON.

${ }^{26}$ We focus on four-quarter changes, so there is no need to seasonally adjust the data. Indeed, for four-quarter changes, non-seasonally adjusted data are preferable but are usually not available.
} 
establishment-side data in the BLS productivity and cost release (and in the Fernald dataset) cover the narrower business sector. To be consistent, we use BLS estimates of employment and hours in the non-business civilian sector. ${ }^{27}$ We subtract the non-business measures from the household-survey measures to create alternative, household-based business measures.

The two surveys have different strengths and weaknesses. Our baseline measures of business-sector hours and employment come from the BLS Productivity and Cost release. Those data rely primarily on the establishment survey, supplemented with information from the household (that is, the CPS) survey on agricultural workers, the self-employed, and unpaid family workers. The CES sample is much larger than the CPS, reducing sampling error. A potential concern with the CES data is that the BLS needs to estimate establishment births and deaths. However, annual revisions to these data benchmark them to near universal unemployment insurance records, which include new firms and exclude dead ones. Thus, revised data greatly reduce non-sampling errors related to the birth-death model. Nevertheless, because of non-reporting, some non-coverage, and interpolation between benchmarks, some errors may remain. ${ }^{28}$

The alternative measure, in contrast, comes entirely from the CPS. The CPS measure covers the entire civilian economy, not just the business sector. This household sample is much smaller than the establishment sample. In addition, the household survey provides estimated population ratios rather than levels of employment. Because of immigration and emigration, there are errors in estimating the population to which these ratios are applied, which may lead to cyclical errors in estimated employment. As a practical matter, the estimated population used by the BLS is smooth during the year but then has jumps-sometimes sizeable-each January when updated population estimates become available.

\footnotetext{
27 Data were downloaded (October 8, 2015) from www.bls.gov/lpc/special requests/us total hrs emp.xlsx. Nonbusiness is total economy less business.

${ }^{28}$ Hagedorn and Manovski (2011) conjecture that there could have been an increase in cyclical measurement error in the establishment survey, reflecting increasing inadequacies in the birth/death model. As a result, in recessions, measured hours may now fall more than true hours. Such a pattern, if it existed, would mechanically lead to a more positive (or less negative) movement in labor productivity or TFP. Again, it is unclear that concerns about the birthdeath model are warranted after the data have undergone their annual revision, which benchmarks them to the (near) universe of unemployment insurance records.
} 
Ramey (2012) notes that there is a difference between average hours reported in the two surveys. Implicitly, there is also a difference between the cyclicality of employment versus average hours in the two surveys. Relative to the CES, the CPS shows less response in bodies, and more response in hours per person. This pattern across the surveys is a priori reasonable. Conceptually, when a person loses a second job, there is one fewer worker in the establishment survey but fewer hours per person in the household survey. 


\section{References}

Aruoba, S. Boragan, Francis X. Diebold, Jeremy Nalewaik, Frank Schorfheide, and Dongho Song. 2015. "Improving GDP Measurement: A Measurement-Error Perspective," Journal of Econometrics, Annals Issue on Innovations in Econometric and Economic Measurement.

Barnichon, Regis. 2010. "Productivity and Unemployment Over the Business cycle." Journal of Monetary Economics 57: 1013-1025.

Barnichon, Regis. 2014. "The Shimer Puzzle and the Endogeneity of Productivity." Manuscript, CREI.

Basu, Susanto. 1996. Cyclical Productivity: Increasing Returns or Cyclical Utilization? Quarterly Journal of Economics 111 (August): 719-751.

Basu, Susanto, and John Fernald. 1995. "Are Apparent Productive Spillovers a Figment of Specification Error?" Journal of Monetary Economics 36 (December): 165-188.

Basu, Susanto, and John Fernald. 1997. "Returns to Scale in U.S. Manufacturing: Estimates and Implications." Journal of Political Economy 105 (April): 249-283.

Basu, Susanto, and Miles Kimball. 1997. "Cyclical Productivity with Unobserved Input Variation." NBER working paper \#5915.

Basu, Susanto, and John Fernald. 2001. "Why is Productivity Procyclical? Why Do We Care?" in New Development in Productivity Analysis, eds. Charles R. Hulten, Edwin R. Dean, and Michael J. Harper, 224-296. NBER. Available at http://www.nber.org/chapters/c10128.

Basu, Susanto, and John Fernald. 2002. "Aggregate Productivity and Aggregate Technology." European Economic Review 46: 963-991.

Basu, Susanto, John Fernald, and Matthew D. Shapiro. 2001. "Productivity Growth in the 1990s: Technology, Utilization, or Adjustment?" Carnegie-Rochester Conference Series on Public Policy 55: 117-165.

Basu, Susanto, John G. Fernald, Nicholas Oulton, and Sylaja Srinivasan. 2004. "The Case of the Missing Productivity Growth, or Does Information Technology Explain Why Productivity Accelerated in the United States but Not the United Kingdom?" In NBER Macroeconomics Annual 2003 eds. Mark Gertler and Kenneth Rogoff, 9-63. Cambridge: MIT Press.

Basu, Susanto, John Fernald, and Miles Kimball. 2006. "Are Technology Improvements Contractionary?" American Economic Review 96(5): 1418-1448. 
Basu, Susanto, John Fernald, Jonas Fisher, and Miles Kimball. 2013. "Sector-Specific Technical Change." Unpublished manuscript, Federal Reserve Bank of San Francisco.

Berger, David. 2012. “Countercyclical Restructuring and Jobless Recoveries," working paper, Yale University.

Bernanke, Ben S., and Martin L. Parkinson. 1991. "Procyclical Labor Productivity and Competing Theories of the Business Cycle: Some Evidence from Interwar U.S. Manufacturing Industries." Journal of Political Economy 99 (3): 439-459. http://www.jstor.org/stable/2937737.

Biddle, Jeff E. 2014. "Retrospectives: The Cyclical Behavior of Labor Productivity and the Emergence of the Labor Hoarding Concept." Journal of Economic Perspectives, 28(2): 197212.

Bils, Mark, and Jang-Ok Cho. 1994. "Cyclical Factor Utilization." Journal of Monetary Economics 33: 319-354.

Bosler, Canyon, John G. Fernald, Bart Hobijn, and Mary C. Daly. 2015. “The Outlook for U.S. Labor Quality Growth." Paper prepared for CRIW Conference, October 2015.

Brynjolfsson, Eric, and Lorin M. Hitt. 2000. "Beyond Computation: Information Technology, Organizational Transformation and Business Performance." Journal of Economic Perspectives 14(4): 23-48.

Brynjolfsson, Eric, and Lorin M. Hitt. 2003. "Computing Productivity: Firm-Level Evidence." Review of Economics and Statistics 85(4): 793-808.

Burda, Michael C., Katie R. Genadek, and Daniel S. Hamermesh. 2015. “Not Working at Work: Loafing, Unemployment and Labor Productivity." IZA Discussion Papers No. 9095. (June).

Burda, Michael C., and Jennifer Hunt. 2011. “What Explains the German Labor Market Miracle in the Great Recession?" Brookings Papers on Economic Activity. 273-335. http://www.jstor.org/stable/41228527.

Burnside, Craig, and Martin Eichenbaum. 1996. "Factor-Hoarding and the Propagation of Business-Cycle Shocks." American Economic Review 86: 1154-1174.

Burnside, Craig, Martin Eichenbaum, and Sergio Rebelo. 1995. "Capital Utilization and Returns to Scale." in NBER Macroeconomics Annual, eds. Ben S. Bernanke and Julio J. Rotemberg.

Byrne, David M., John G. Fernald, and Marshall B. Reinsdorf. 2016. "Does the United States Have a Productivity Problem or a Measurement Problem?"Manuscript under preparation for Brookings Papers on Economics Activity (March). 
Caballero, Ricardo J., and Richard K. Lyons. 1992. "External Effects in U.S. Procyclical Productivity." Journal of Monetary Economics 29: 209-226.

Cantore, Cristiano, Filippo Ferroni, and Miguel A. León-Ledesma. 2014. "The Dynamics of Hours Worked and Technology." Manuscript.

Christiano, Larry J., Martin Eichenbaum, and Charles L. Evans. 2005. “Nominal Rigidities and the Dynamic Effects of a Shock to Monetary Policy." Journal of Political Economy 113(1): $1-45$.

Cociuba, Simona, Edward C. Prescott, and Alexander Ueberfeldt. 2012. "U.S. Hours and Productivity Behavior Using CPS Hours Worked Data: 1947-III to 2011-IV." Unpublished manuscript.

Corrado, Carol A., Charles R. Hulten, and Daniel E. Sichel. 2006. "Intangible Capital and Economic Growth." NBER Working Papers 11948, National Bureau of Economic Research, Inc.

Corrado, Carol, Jonathan Haskel, Cecilia Jona-Lasinio, and Massimiliano Iommi. 2014. "Intangibles and Industry Productivity Growth: Evidence from the EU." Manuscript available at www.intan-invest.net.

Daly, Mary C., John G. Fernald, Oscar Jordà, and Fernanda Nechio. 2011. “Okun's Macroscope: Changes in the Cyclical Behavior of Productivity and the Comovement between Output and Unemployment." Federal Reserve Bank of San Francisco working paper.

Daly, Mary C., John G. Fernald, Oscar Jordà, and Fernanda Nechio. 2014. “Interpreting Deviations from Okun's Law." Federal Reserve Bank of San Francisco Economic Letter.

Daly, Mary C., John G. Fernald, Oscar Jordà, and Fernanda Nechio. 2015. “Output and Unemployment Dynamics." Federal Reserve Bank of San Francisco working paper, 2013-32 (updated draft July 2015).

Daula, Thomas, and Benjamin Kay. 2014. "International Employment and the Business Cycle: New Stylized Facts with an Application to the Great Moderation." Unpublished manuscript.

Fay, Jon A., and James L. Medoff. 1985. "Labor and Output Over the Business Cycle: Some Direct Evidence." American Economic Review 75(4): 638-655.

Fernald, John G. 2007. “Trend Breaks, Long-Run Restrictions, and Contractionary Technology Improvement." Journal of Monetary Economics 54: 2467-2485. 
Fernald, John G. 2014a. “ A Quarterly, Utilization-Adjusted Series on Total Factor Productivity." Federal Reserve Bank of San Francisco Working Paper 2012-19, April. Data supplement at http://www.frbsf.org/economics/economists/jfernald/quarterly_tfp.xls

Fernald, John G. 2014b. " Productivity and Potential Output before, during, and after the Great Recession." Forthcoming, NBER Macroeconomics Annual 2014.

Fernald, John, and Brent Neiman. 2011. "Growth Accounting with Misallocation: Or, Doing Less with More in Singapore." American Economic Journal: Macroeconomics 3(2): 29-74.

Foster, Lucia, John C. Haltiwanger, and C. J. Krizan. 2001. “Aggregate Productivity Growth: Lessons from Microeconomic Evidence." New Developments in Productivity Analysis, Charles R. Hulten, Edwin R. Dean, and Michael J. Harper, eds., University of Chicago Press.

Foster, Lucia, John C. Haltiwanger, and C. J. Krizan. 2006. "Market Selection, Reallocation, and Restructuring in the U.S. Retail Trade Sector in the 1990s." Review of Economics and Statistics 88(4): 748-758.

Francis, Neville, and Valerie A. Ramey. 2005. "Is the Technology-Driven Real Business Cycle Hypothesis Dead? Shocks and Aggregate Fluctuations Revisited." Journal of Monetary Economics 52(8): 1379-1399.

Galí, Jordi. 1999. "Technology, Employment, and the Business Cycle: Do Technology Shocks Explain Aggregate Fluctuations?" American Economic Review 89(1): 249-271.

Galí, Jordi, J. David López -Salido, and Javier Vallés. 2003. “Technology Shocks and Monetary Policy: Assessing the Fed's Performance." Journal of Monetary Economics 50(4): 723-743.

Galí, Jordi, and Luca Gambetti. 2009. "On the Sources of the Great Moderation." American Economic Journal: Macroeconomics 1(1): 26-57.

Gali, Jordi, and Thijs van Rens. 2014. "The Vanishing Procyclicality of Labor Productivity." CEPR Discussion Paper \#DP9853.

Garin, Julio, Michael Pries, and Eric Sims. 2013. "Reallocation and the Changing Nature of Business Cycle Fluctuations." Unpublished working paper.

Gordon, Robert J. 2003. “Are Procyclical Productivity Fluctuations a Figment of Measurement Error?" in Productivity Growth, Inflation, and Unemployment: The Collected Essays of Robert J. Gordon. 239-272. Cambridge, Cambridge University Press.

Gordon, Robert J. 2010. “Okun's Law, Productivity Innovations, and Conundrums in Business Cycle Dating." American Economic Review: Papers and Proceedings 100(2). 
Gordon, Robert J. 2011. “The Evolution of Okun's Law and of Cyclical Productivity Fluctuations in the United States and in the EU-15." Manuscript prepared for presentation at the EES/IAB Workshop on Labor Market Institutions and the Macroeconomy, June 17-18, 2011.

Gorodnichenko, Yuriy, and Matthew D. Shapiro. 2011. "Using the Survey of Plant Capacity to Measure Capital Utilization." US Census Bureau Center for Economic Studies Paper No. CES-WP-11-19.

Griliches, Zvi, and Dale W. Jorgenson. 1966. "Sources of Measured Productivity Change: Capital Input." The American Economic Review 56 (1/2): 50-61. http://www.jstor.org/stable/1821267.

Hall, Robert E. 1988. “The Relation between Price and Marginal Cost in U.S. Industry." Journal of Political Economy 96: 921-947.

Hall, Robert E. 1990. “Invariance Properties of Solow's Productivity Residual. in Diamond, P., ed. Growth, Productivity, Employment. Cambridge, MA, MIT Press.

Hagedorn, Marcus, and Iourii Manovskii 2011. "Productivity and the Labor Market: Comovement over the Business Cycle." International Economic Review 52(3): 603-619.

Helpman, Elhanan, and Manuel Trajtenberg. 1998. General Purpose Technologies and Economic Growth MIT press.

Hultgren, Thor. 1960. "Changes in Labor Cost during Cycles in Production and Business." NBER Occasional Paper, No. 74. http://papers.nber.org/books/hult60-1.

Inklaar, Robert. 2007. "Cyclical Productivity in Europe and the United States: Evaluating the Evidence on Returns to Scale and Input Utilization." Economica New Series 74(296):822841.

Jordà, Òscar. 2005. "Estimation and Inference of Impulse Responses by Local Projections." American Economic Review 95(1): 161-182.

Jorgenson, Dale W., Frank Gollop, and Barbara Fraumeni. 1987. Productivity and U.S. Economic Growth. Cambridge: Harvard University Press.

Jorgenson, Dale, and Zvi Griliches. 1967. “The Explanation of Productivity Change." The Review of Economic Studies 34 (3): 249-283. http://www.jstor.org/stable/2296675.

Jorgenson, Dale, Mun Ho, and David Samuels. 2012. "Information Technology and U.S. Productivity Growth." in Industrial Productivity in Europe, eds. Matilde Mas and Robert Stehrer, 34-65. Northampton, Massachusetts, Edward Elgar. 
King, Robert G., and Sergio Rebelo. 2000. "Resuscitating Real Business Cycles." in Handbook of Macroeconomics, eds. John Taylor and Michael Woodford, 927-1007. North-Holland.

Kydland, Finn E., and Edward C. Prescott. 1982. "Time to build and aggregate fluctuations." Econometrica, 50(6): 1345-1370.

Lazear, Edward P., Kathryn L. Shaw, and Christopher Stanton. forthcoming "Making Do with Less: Working Harder During Recessions." in The Labor Market in the Aftermath of the Great Recession, ed. David Card and Alexandre Mas.

Lucas, Robert E. 1970. "Capacity, Overtime, and Empirical Production Functions." American Economic Review Papers and Proceedings 60( 2): 23-27.

Marris, Robin. 1964. The Economics of Capital Utilisation. Cambridge Univ. Press.

McGrattan, Ellen R., and Edward C. Prescott. 2007. “Unmeasured Investment and the Puzzling U.S. Boom in the 1990s." NBER working paper 13499.

McGrattan, Ellen R., and Edward C. Prescott. 2012. "The Great Recession and Delayed Economic Recovery: A Labor Productivity Puzzle." in Government Policies and the Delayed Economic Recovery, eds. Lee E. Ohanian, John B. Taylor, Ian Wright, 115-154.

Mitchell, Wesley C. 1913. Business cycle. University of California Press.

Nalewaik, Jeremy J. 2010. "The Income- and Expenditure-Side Estimates of U.S. Output Growth." Brookings Papers on Economic Activity 41(1): 71-127.

Nucci, F., and M. Riggi. 2009. "The Great Moderation and Changes in the Structure of Labor Compensation." Unpublished manuscript.

Oi, Walter Y., 1962. "Labor as a Quasi-Fixed Factor." Journal of Political Economy.70(6): 538-555.

Okun, Arthur. 1963. "Potential GNP: Its Measurement and Significance." Cowles Foundation Paper 190 (reprinted from the 1962 Proceedings of the Business and Economics Statistics Section of the American Statistical Association). Available at http://cowles.econ.yale.edu/P/cp/py1963.htm.

Oliner, Stephen D., Daniel E. Sichel, and Kevin J. Stiroh. 2007. “Explaining a Productive Decade." Brookings Papers on Economic Activity, V2007 (1): 81-137.

Ramey,Valerie A. 2012. "The Impact of Hours Measures on the Trend and Cycle Behavior of U.S. Labor Productivity." Unpublished, University of California San Diego.

Ramey, Valerie A., and Daniel J. Vine. 2006. “Declining Volatility in the U.S. Automobile Industry." American Economic Review 96(5): 1876-1889. 
Romer, Christina D., and David H. Romer. 2004. "A New Measure of Monetary Shocks: Derivation and Implications." American Economic Review 94(4): 1055-1084.

Rotemberg, Julio J., and Michael Woodford. 1995. “Dynamic General Equilibrium Models with Imperfectly Competitive Product Markets." in Frontiers of Business Cycle Research, ed. Thomas F. Cooley, 243-293. Princeton: Princeton University Press.

Rua, António. 2010. “Measuring Comovement in the Time-Frequency Space." Journal of Macroeconomics 32: 685-691.

Sbordone, Argia M. 1997. “Interpreting the Procyclical Productivity of Manufacturing Sectors: External Effects or Labor Hoarding?" Journal of Money, Credit and Banking. 29(1): 26-45.

Shapiro, Matthew D. 1993. "Cyclical Productivity and the Workweek of Capital." The American Economic Review Papers and Proceedings 83( 2): 229-233."

Shapiro, Matthew D. 1996. "Macroeconomic Implications of Variation in the Workweek of Capital." Brookings Papers on Economic Activity (2): 79-119.

Shimer, R. 2005. "The Cyclical Behavior of Equilibrium Unemployment and Vacancies." American Economic Review, 95(1): 25-49.

Smets, Frank, and Rafael Wouters. 2007. "Shocks and Frictions in US Business Cycles: A Bayesian DSGE Approach." American Economic Review, 97(3): 586-606.

Solow, Robert M. 1957. "Technological Change and the Aggregate Production Function." Review of Economics and Statistics 39: 312-320.

Solow, Robert M. 1964. 1964. "Draft of Presidential Address on the Short Run Relation of Employment and Output." Robert Solow papers, David M. Rubenstein Rare Book \& Manuscript Library, Duke University. Box 70, Folder 1964, dated 1964.

Stiroh, K. J. 2009. “Volatility Accounting: A Production Perspective on Increased Economic Stability." Journal of the European Economic Association 7(4): 671-696.

Stock, James H., and Mark W. Watson. 2002. "Has the Business Cycle Changed and Why?" NBER Macroeconomics Annual. 17: 159-218.

Wang, J. Christina. 2014. “Vanishing Procyclicality of Productivity? Industry Evidence.” Federal Reserve Bank of Boston working paper No. 14-15.

Wolff, Edward N. 2002. "Productivity, Computerization, and Skill Change." National Bureau of Economic Research Working Paper 8743. 


\section{ACRONYMS USED}

BFK: Basu, Fernald, and Kimball (2006).

BLS: Bureau of Labor Statistics

CES: Current Establishment Survey, a monthly survey of establishments done by the BLS

CPS: Current Population Survey, a monthly survey of households done by the BLS

RBC: Real Business Cycle

TFP: Total Factor Productivity, measured as output growth less share-weighted (observed) capital and labor 


\section{Table 1: Cyclical correlations between labor productivity, output, and inputs}

a. Labor productivity and output

\begin{tabular}{lcccc}
\hline Filter & 1950:Q1-2015:Q2 & 1950:Q1-1983:Q4 & 1984:Q1-2015:Q2 & Subperiod Diff. \\
\hline Hodrick-Prescott & 0.395 & 0.572 & 0.028 & $-0.544^{* *}$ \\
Bandpass & 0.398 & 0.568 & 0.037 & $-0.531^{* *}$ \\
Christiano-Fitzgerald & 0.460 & 0.580 & 0.217 & $-0.363^{* *}$ \\
First Difference & 0.634 & 0.685 & 0.481 & $-0.204^{*}$ \\
\hline \hline
\end{tabular}

b. Labor productivity and hours

\begin{tabular}{lcccc}
\hline Filter & 1950:Q1-2015:Q2 & 1950:Q -1983:Q4 & 1984:Q1-2015:Q2 & Subperiod Diff. \\
\hline Hodrick-Prescott & -0.100 & 0.136 & -0.466 & $-0.602^{* *}$ \\
Bandpass & -0.084 & 0.147 & -0.454 & $-0.601^{* *}$ \\
Christiano-Fitzgerald & -0.015 & 0.165 & -0.318 & $-0.483^{* *}$ \\
First Difference & -0.057 & 0.047 & -0.307 & $-0.354^{* *}$ \\
\hline \hline
\end{tabular}

Note: All the filters are applied to the log level of the relevant series. Both the bandpass filter and the CF (ChristianoFitzgerald 2003) filter are specified with frequency band 6-32 quarters. HP: Hodrick-Prescott filter with $\lambda=1600$. Sample period is 1950:Q1-2015:Q2. ** denotes that the difference in correlation is significant at the 5 percent level, while * denotes significance at the 1 percent level. 
Table 2: Cyclical correlations between TFP, output, and inputs

a. TFP and output

\begin{tabular}{lcccc}
\hline Filter & 1950:Q-2015:Q2 & 1950:Q1-1983:Q4 & 1984:Q1-2015:Q2 & Subperiod Diff. \\
\hline Hodrick-Prescott & 0.813 & 0.878 & 0.643 & $-0.235^{* *}$ \\
Bandpass & 0.816 & 0.877 & 0.648 & $-0.228^{* *}$ \\
Christiano-Fitzgerald & 0.827 & 0.878 & 0.700 & $-0.178^{* *}$ \\
First Difference & 0.852 & 0.886 & 0.741 & $-0.146^{* *}$ \\
\hline \hline
\end{tabular}

b. TFP and hours

\begin{tabular}{lcccc}
\hline Filter & 1950:Q1-2015:Q2 & 1950:Q1-1983:Q4 & 1984:Q1-2015:Q2 & Subperiod Diff. \\
\hline Hodrick-Prescott & 0.441 & 0.571 & 0.208 & $-0.363^{* *}$ \\
Bandpass & 0.457 & 0.582 & 0.217 & $-0.365^{* *}$ \\
Christiano-Fitzgerald & 0.469 & 0.585 & 0.240 & $-0.345^{* *}$ \\
First Difference & 0.294 & 0.378 & 0.086 & $-0.293^{*}$ \\
\hline \hline
\end{tabular}

Note: All the filters are applied to the log level of the relevant series. Both the bandpass filter and the CF (ChristianoFitzgerald, 2003) filter are specified with frequency band 6-32 quarters. HP: Hodrick-Prescott filter with $\lambda=1600$.

Sample period is 1950:Q1-2015:Q2. ** denotes that the difference in correlation is significant at the 5 percent level, while * denotes significance at the 1 percent level. 


\section{Table 3: Cyclical correlations between utilization-adjusted TFP, output, and inputs}

a. Utilization-adjusted TFP and output

\begin{tabular}{lcccc}
\hline Filter & 1950:Q1-2015:Q2 & 1950:Q1-1983:Q4 & 1984:Q1-2015:Q2 & Subperiod Diff. \\
\hline Hodrick-Prescott & -0.176 & -0.158 & -0.216 & -0.058 \\
Bandpass & -0.245 & -0.252 & -0.236 & 0.016 \\
Christiano-Fitzgerald & -0.254 & -0.227 & -0.316 & -0.089 \\
First Difference & 0.090 & 0.018 & 0.262 & $0.244^{*}$ \\
\hline \hline
\end{tabular}

b. Utilization-adjusted TFP and hours

\begin{tabular}{lcccc}
\hline Filter & 1950:Q1-2015:Q2 & 1950:Q1-1983:Q4 & 1984:Q1-2015:Q2 & Subperiod Diff. \\
\hline Hodrick-Prescott & -0.435 & -0.385 & -0.516 & -0.131 \\
Bandpass & -0.497 & -0.464 & -0.547 & -0.084 \\
Christiano-Fitzgerald & -0.532 & -0.456 & -0.662 & $-0.206^{*}$ \\
First Difference & -0.393 & -0.425 & -0.334 & 0.091 \\
\hline \hline
\end{tabular}

Note: All the filters are applied to the log level of the relevant series. Both the bandpass filter and the CF (ChristianoFitzgerald, 2003) filter are specified with frequency band 6-32 quarters. HP: Hodrick-Prescott filter with $\lambda=1600$. Sample period is 1950:Q1-2015:Q2. ** denotes that the difference in correlation is significant at the 5 percent level, while * denotes significance at the 1 percent level. 


\section{Figure 1: Changing cyclicality in rolling correlations}
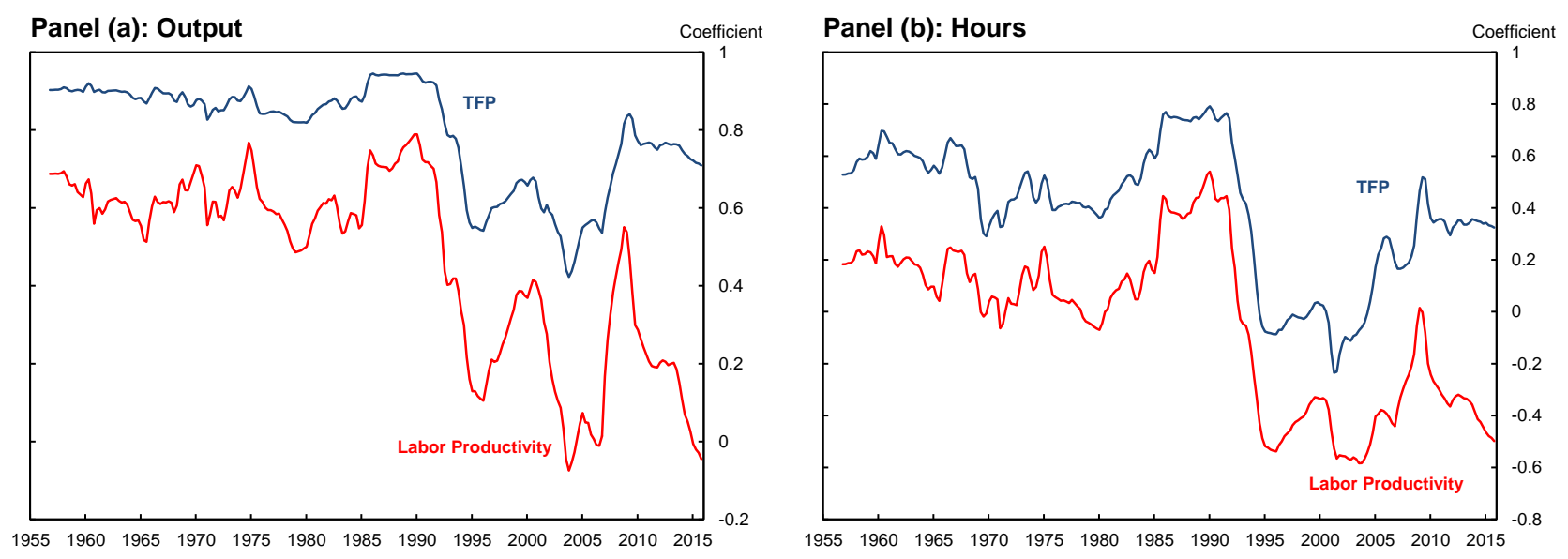

Notes: 40-quarter (trailing) rolling correlations of four-quarter growth in TFP and labor productivity with four-quarter growth in output (left panel a) and hours (right panel b). Source: Fernald (2014a). 
Figure 2: Robustness of rolling correlations to measures of output and hours
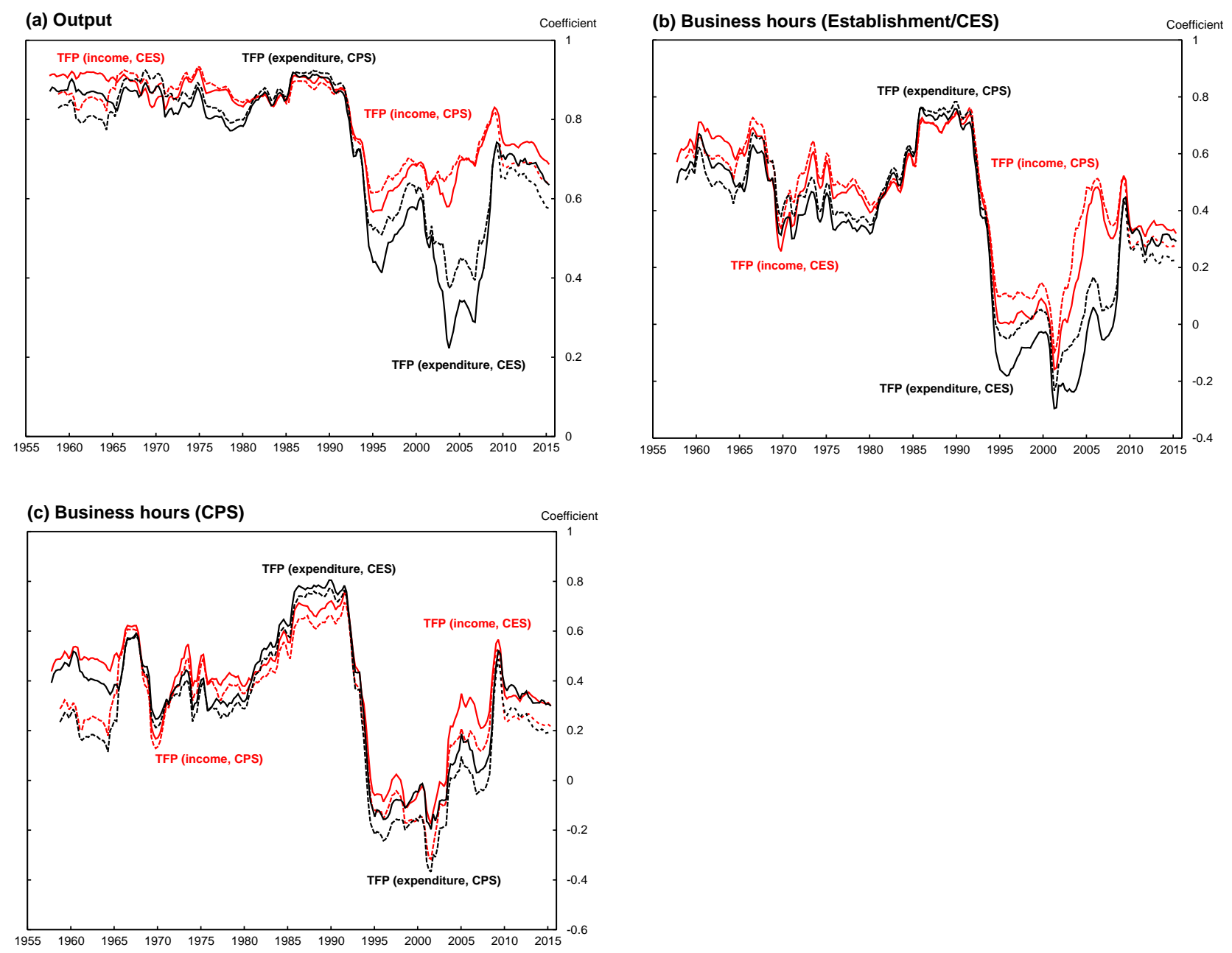

Notes: 40-quarter rolling correlations of four-quarter growth in business-sector TFP, with four-quarter growth in output (panel a), establishment-survey (CES) hours (panel b), and household-survey (CPS) hours (panel c). TFP measures are calculated with either income or expenditure measures of output, and either CES or CPS measure of hours, as shown. Source: Fernald (2014a). 
Figure 3: Rolling correlations of non-business variables

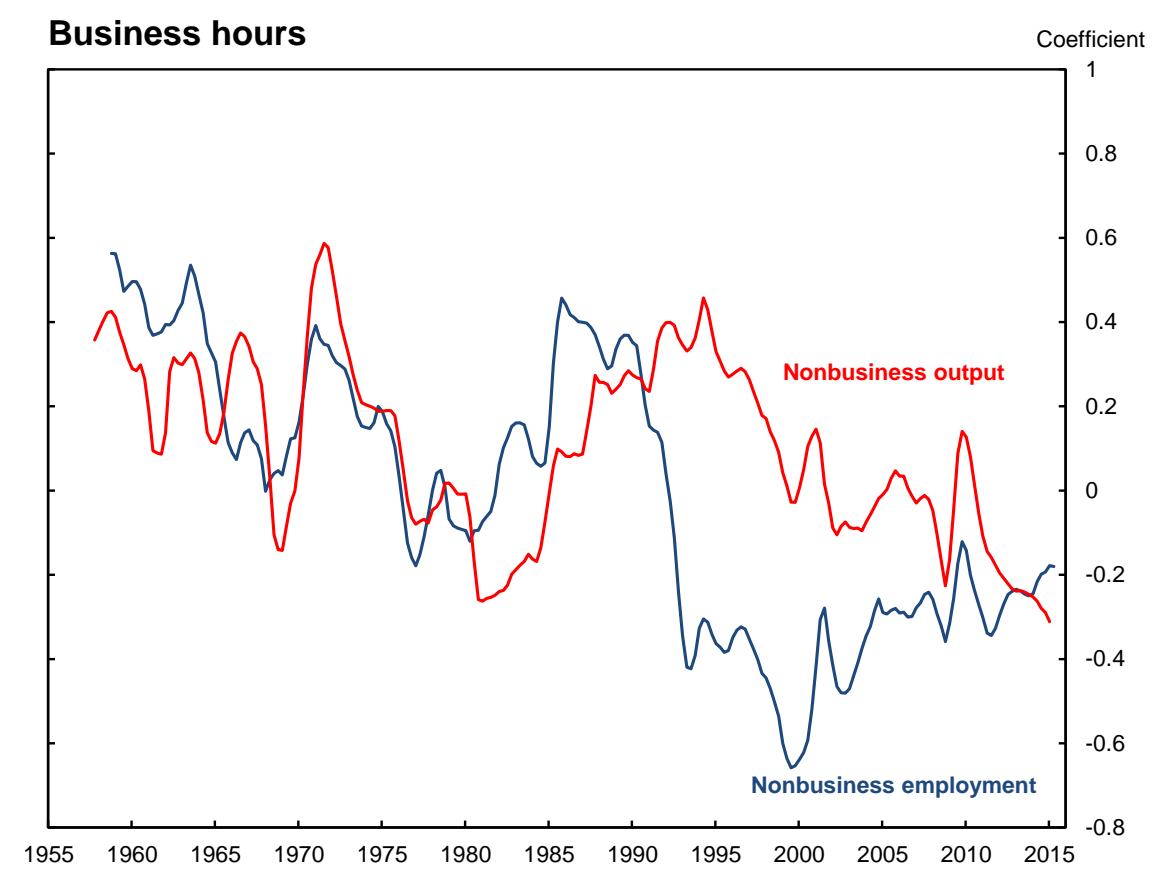

Notes: 40-quarter rolling correlations of four-quarter growth in business hours, with non-business (government, household, and non-profits) employment and output. Source : Fernald (2014a). 


\section{Figure 4: Rolling correlations for utilization-adjusted TFP and utilization}

(a) Utilization-adjusted TFP

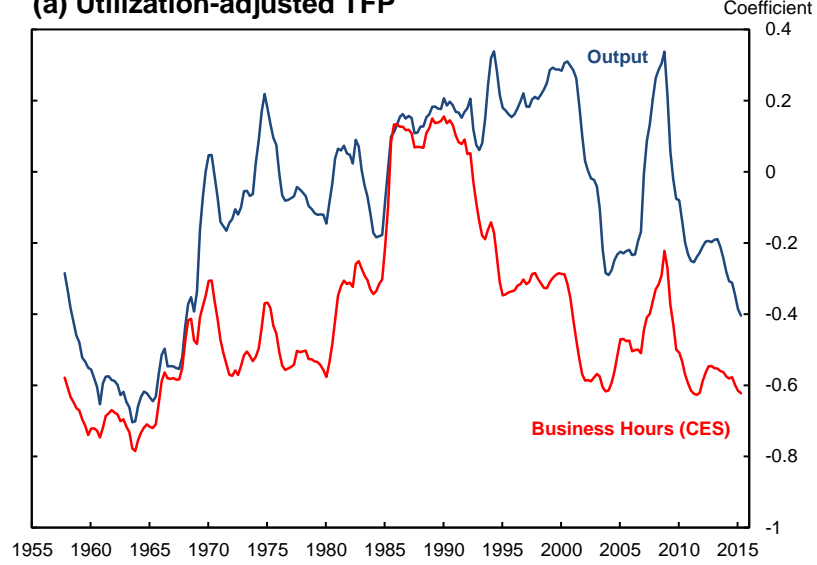

(b) Utilization Coefficient

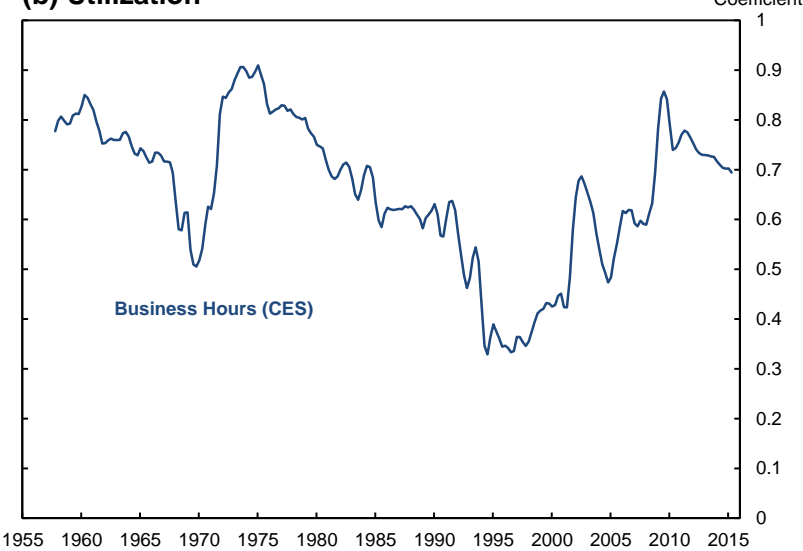

Notes: 40-quarter rolling correlations of four-quarter growth in utilization-adjusted TFP (panel a) and utilization (panel b), with the variables shown (either output or business hours). Source: Fernald (2014a). 
Figure 5: Why has TFP become less volatile?

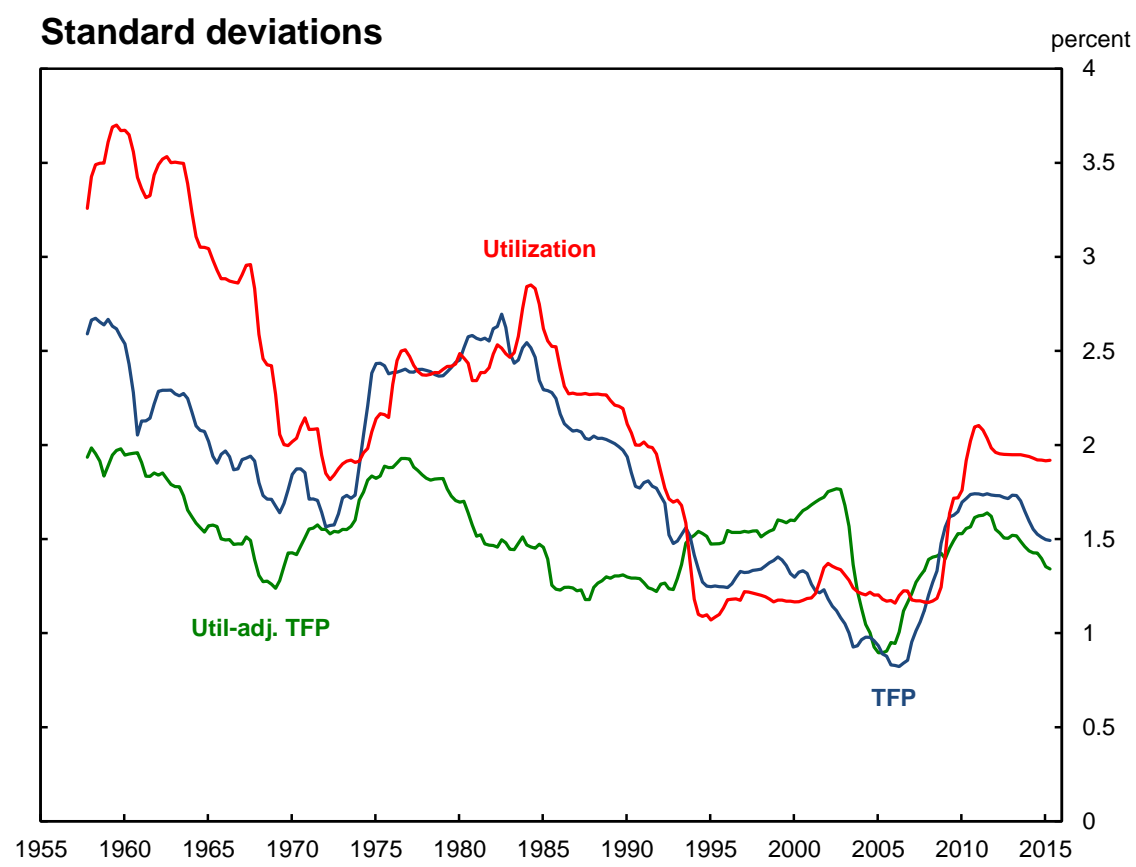

Notes: Rolling standard deviations of four-quarter log changes in TFP, utilization, and utilization-adjusted TFP. Source: Fernald (2014a). 


\section{Figure 6: Impulse responses to technology shocks, business sector}

\section{(a) Average weekly hours}

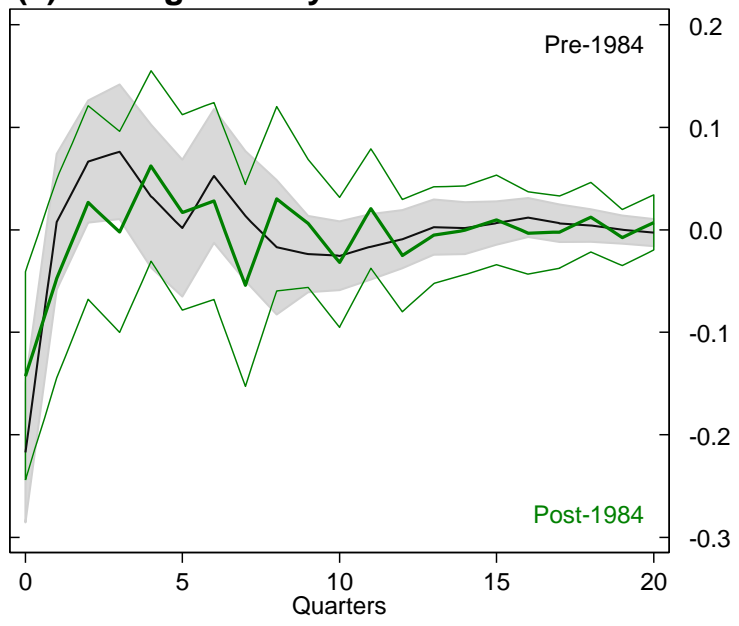

(c) Employment

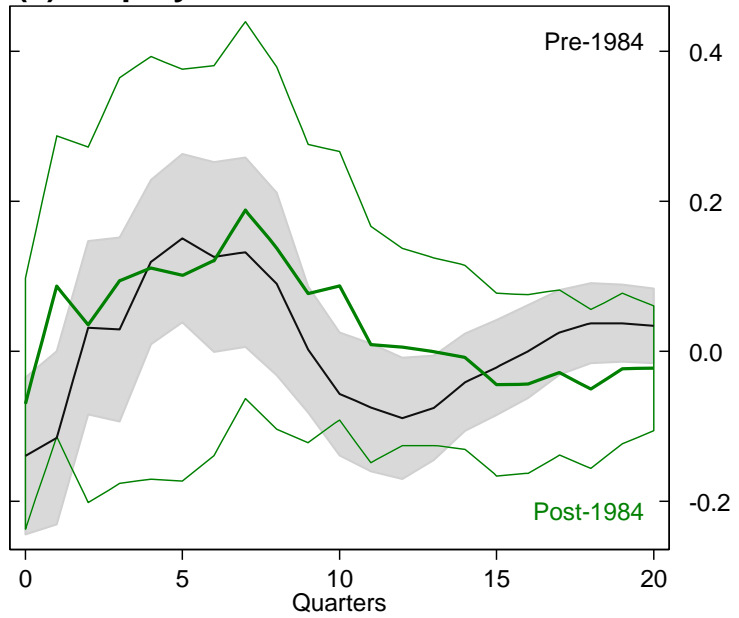

\section{(b) Utilization}

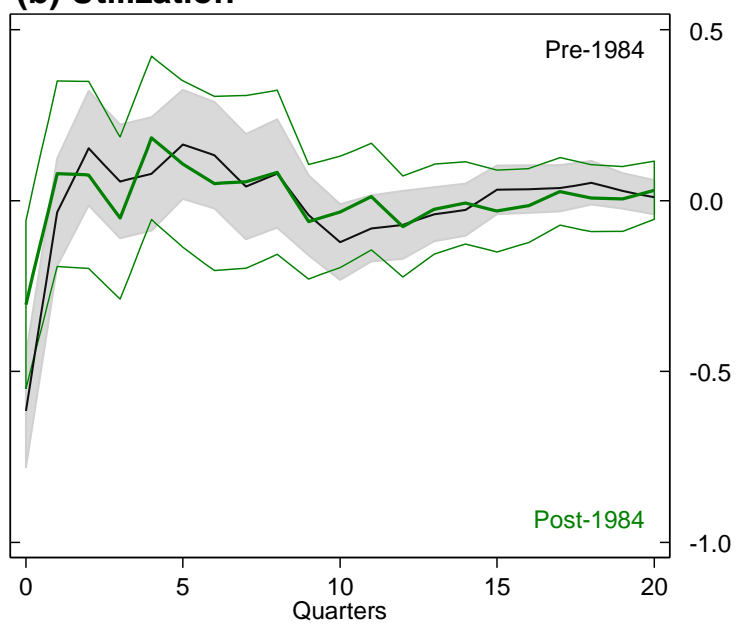

(d) Output

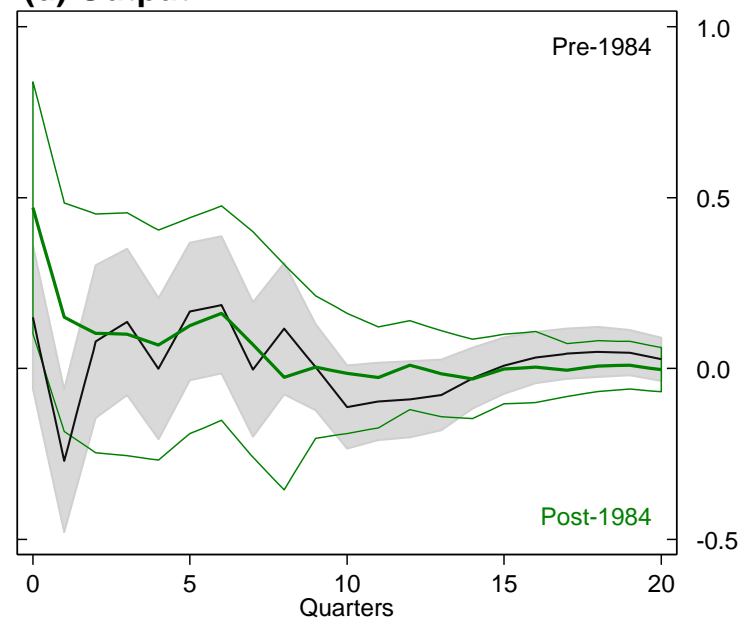

Notes: Each panel plots the impulse responses of the indicated variable to a one-percentage-point increase in utilization-adjusted TFP (from a bivariate VAR, with utilization-adjusted TFP ordered second). The black line depicts the responses for the 1950:Q1-1983:Q4 sample, along with bootstrapped 90 percent confidence band depicted as the grey area. The green line is for the 1984:Q1-2015:Q2 sample, along with 90 percent confidence band. 